\title{
AVALIAÇÃO DOS TEORES FOLIARES DE MICRONUTRIENTES EM CITROS EM FUNÇÃO DA APLICAÇ̃̃O DE FUNGICIDAS, SAIS E QUELATIZADOS
}

\section{MARCELO MELARATO SILVA}

Engenheiro Agronômo

\section{Orientador: Prof. Dr. GODOFREDO CESAR VITTI}

\begin{abstract}
Dissertação apresentada à Escola Superior de Agricultura
"Luiz de Queiroz", Universidade de São Paulo, para obtenção do título de Mestre em Agronomia, Área de Concentração: Solos e Nutrição de Plantas
\end{abstract}

PIRACICABA

Estado de São Paulo - Brasil

Outubro - 1996 
Dados Internacionais de Catalogação na Publicação (CIP)

DIVISÃO DE BIBLIOTECA E DOCUMENTAÇĀO - Campus “Luiz de Queiroz"/USP

Silva, Marceio Melarato

Avaliação dos teores foliares de micronutrientes em citros em função da aplicação

de fungicidas, sais e quelatizados / Marcelo Melarato Silva. - Piracicaba, 1996.

58 p. : il.

Dissertação (mestrado) - - Escola Superior de Agricuitura Luiz de Queiroz, 1996.

Bibliografia.

1. Fruta citrica - Diagnose foliar 2. Fruta citrica - Nutrição 3. Fungicida em fruta citrica - Aplicação 4. Micronutriente em fruta citrica - Avaliação l. Titulo

CDD 634.3 
AVALIAÇÃO DOS TEORES FOLIARES DE MICRONUTRIENTES EM CITROS EM FUNÇÃO DA APLICAÇÃO DE FUNGICIDAS, SAIS E QUELATIZADOS

MARCELO MELARATO SILVA

Aprovado em: 27.11.1996

Comissão Julgadora:

Prof. Dr. GODOFREDO CESAR VITTI

ESALQ/USP

Prof. Dr. ANTONIO ROQUE DECHEN

ESALQ/USP

Dr. JOAQUIM TEÓFILO SOBRINHO

CCSM/IAC

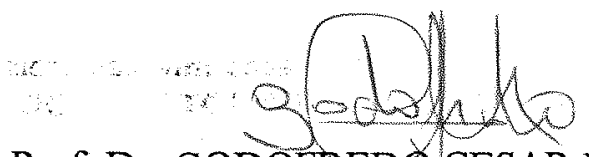

Prof. Dr. GODOFREDOCESAR VITTI

Orientador 
Aos meus pais Eduardo e Yvette e aos meus irmãos pela paciência e apoio nesta etapa vivida.

DEDICO 


\section{AGRADECIMENTOS}

- $\quad$ À Deus pela presença constante em minha vida.

- Aos meus pais Eduardo Silva e Yvette Melarato Silva, pelo acompanhamento incasável desde os primeiros passos de minha educação.

- $\quad$ Ao Prof. Dr. Godofredo Cesar Vitti, pela amizade e orientação.

- À Empresa Catapani nas pessoas do Sr. José Renato Andrade Catapani e Sr. Osmar Aparecido Justino, pela cessão da área e pelo fornecimento dos recursos que possibilitaram o desenvolvimento deste trabalho de pesquisa e do meu curso de pósgraduação.

- $\quad$ A CAPES (Coordenadoria de Aperfeiçoamento de Pessoal do Ensino Superior) pela bolsa de estudo concedida durante a realização do curso.

- Ao Departamento de Ciência do Solo da ESALQ/USP, pela imprescindível colaboração na realização desse trabalho.

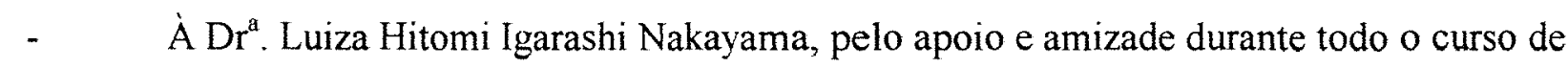
mestrado. 
- À Srta. Adriana Vacchi, funcionária do Departamento de Ciência do Solo da ESALQ/USP, pela colaboração concedida.

- Aos Engs. Agrs. José Eduardo da Silva e Salvador Parducci, pela colaboração e contribuição na execução deste trabalho.

- Ao Dr. Joaquim Teófilo Sobrinho do CCSM/IAC e ao Prof. Dr. Antonio Roque Dechen da ESALQ/USP, por terem me dado a honra de participarem da banca examinadora deste trabalho.

- Ao Sr. Valdecir Domingues, funcionário da Empresa Catapani, pela colaboração na instalação e condução do experimento.

- À Bibliotecária Eliana Garcia Sabino da ESALQ/USP, pela ajuda nas correções bibliográficas. 


\section{SUMÁRIO}

Página

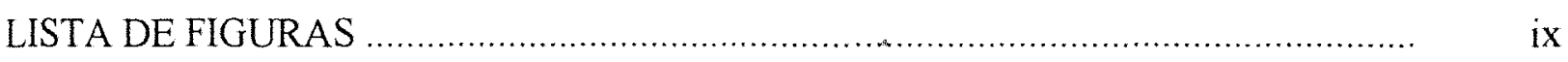

LISTA DE TABELAS …..................................................................................... xi

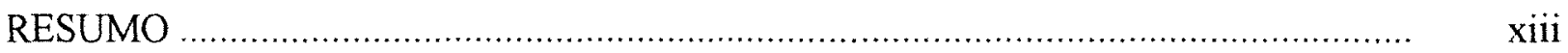

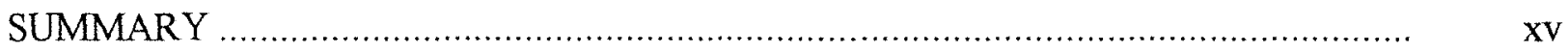

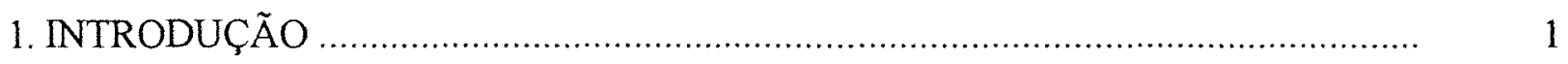

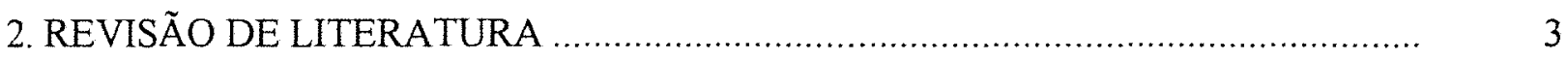

2.1. Funções e exigências de cobre, manganês, zinco e boro .......................................... 4

2.1.1. Funções do Cobre ...................................................................................

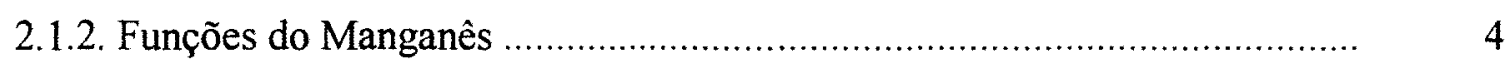

2.1.3. Funções do Zinco .............................................................................. 5

2.1.4. Funções do Boro ................................................................................... 5

2.1.5. Exigências de cobre, manganês, zinco e boro .......................................... 5

2.2. Avaliação do estado nutricional ........................................................................ 6

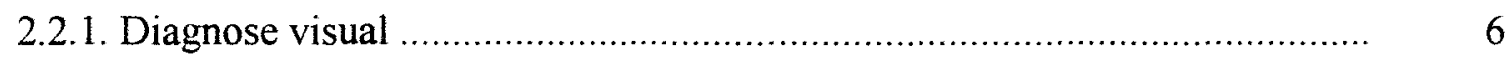

2.2.1.1. Sintomas de deficiência de cobre ................................................. 6

2.2.1.2. Sintomas de deficiência de manganês …………….........................

2.2.1.3. Sintomas de deficiência de zinco .............................................

2.2.1.4. Sintomas de deficiência de boro ................................................. 8

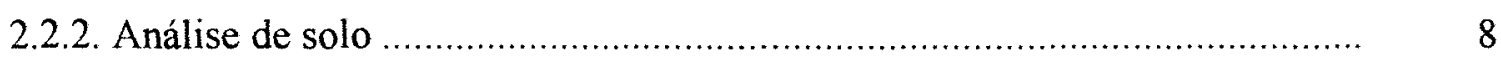

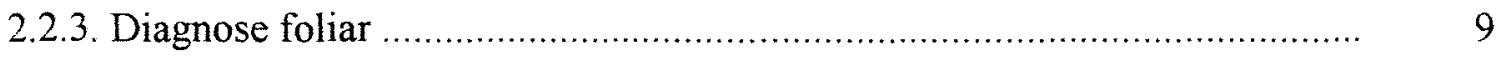

2.3. Causas da deficiência ou excesso de cobre, manganês, zinco e boro ..................... 


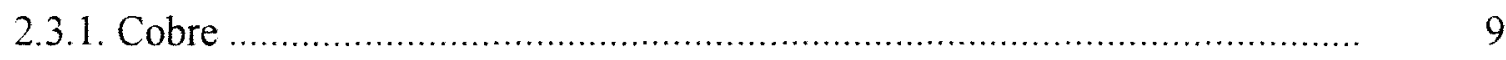

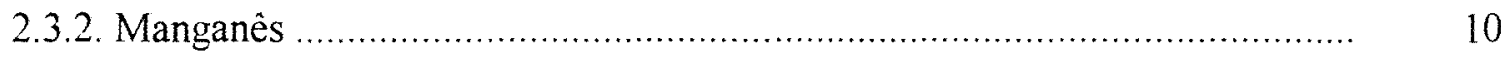

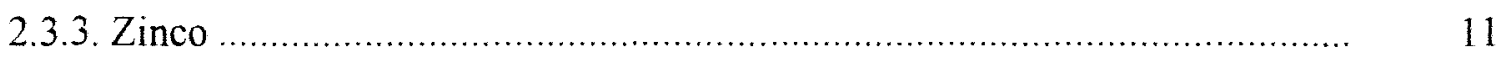

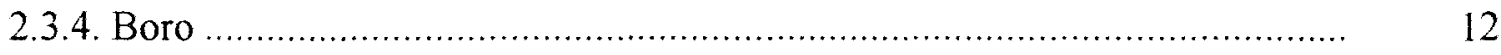

2.4. Interações e respostas a cobre, manganês, zinco e boro ….................................... 12

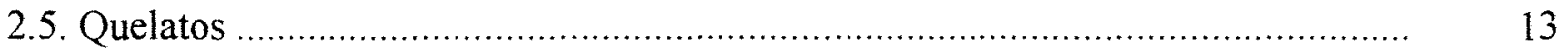

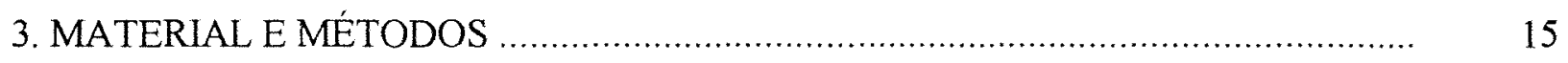

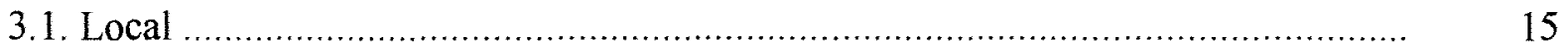

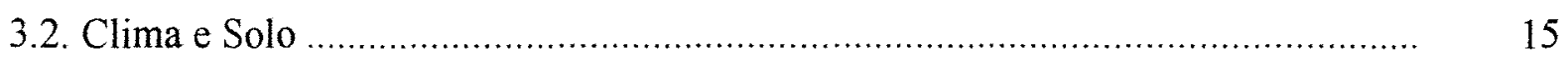

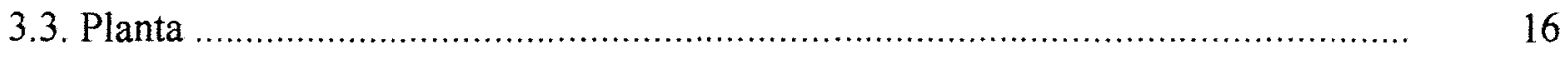

3.4. Delineamento experimental e tratamento ......................................................... 16

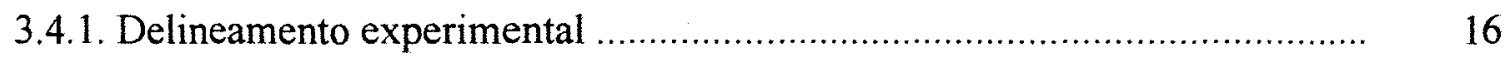

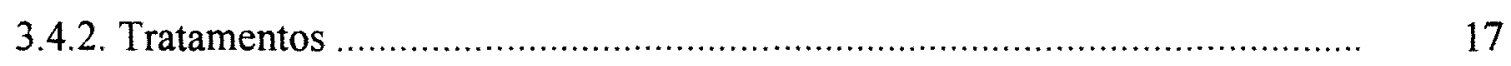

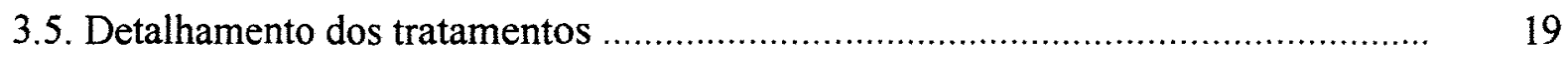

3.6. Instalação e Condução do experimento …………….......................................... 21

3.7. Avaliação do experimento ……….................................................................. 22

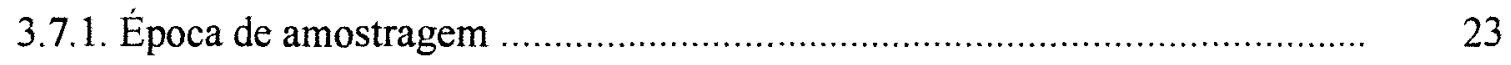

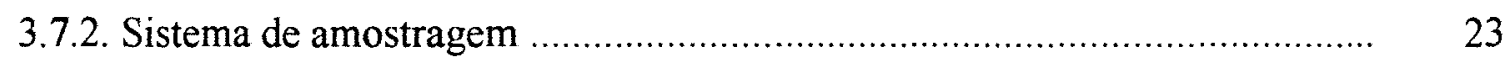

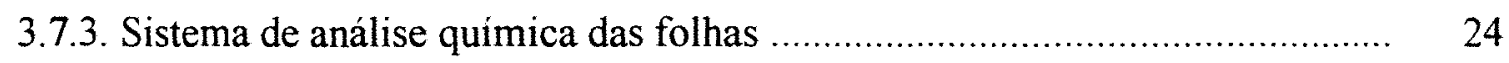

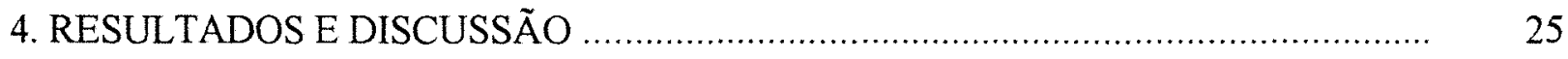

4.1. Variações nos teores foliares de nutrientes (área 1) ……………….................... 25

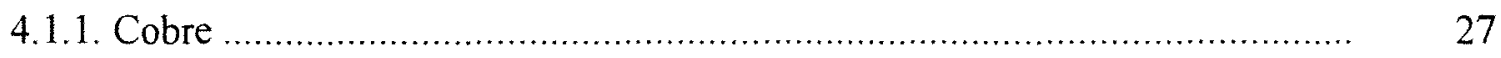

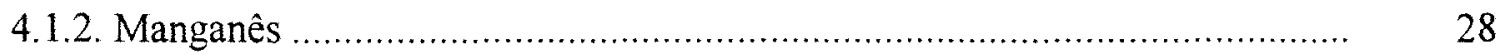




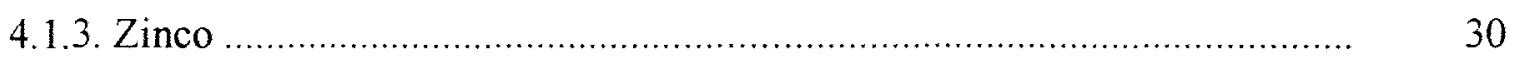

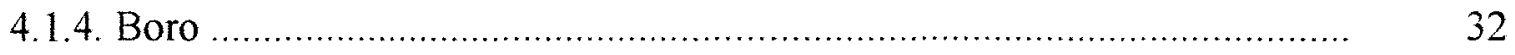

4.2. Variação nos teores foliares de nutrientes (Área 2) …….................................... 33

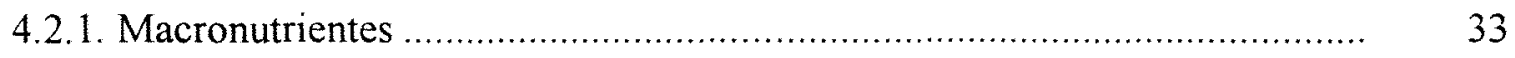

4.2.1.1. Nitrogênio …….................................................................... 36

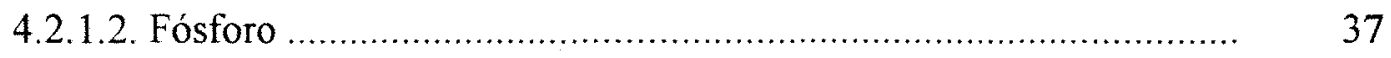

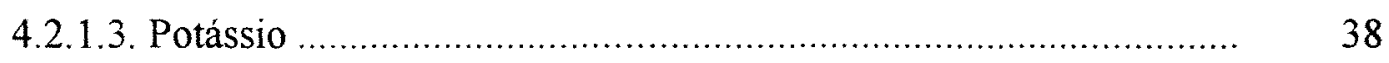

4.2.1.4. Cálcio e Magnésio ……........................................................... 39

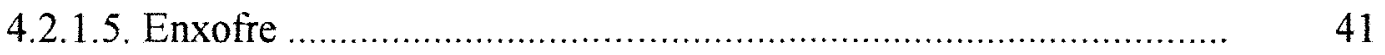

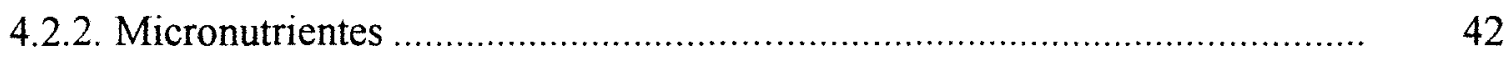

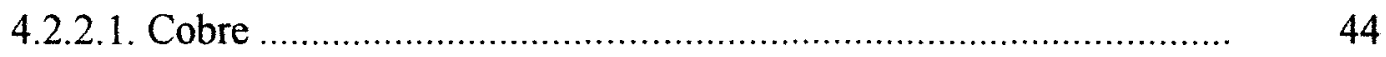

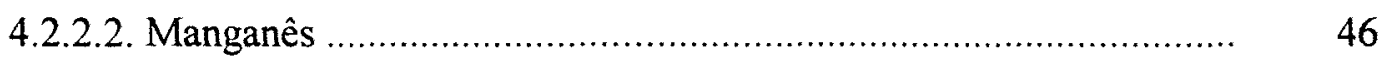

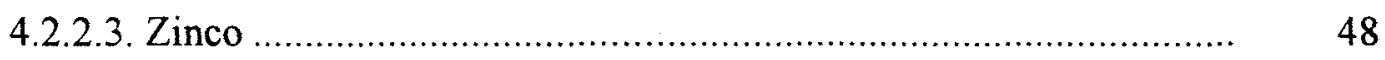

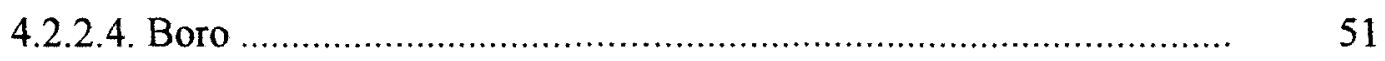

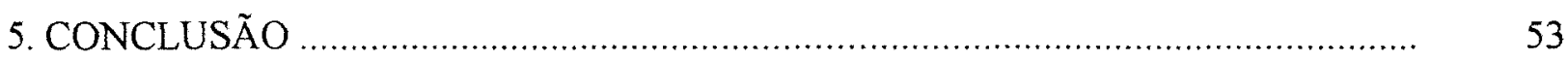

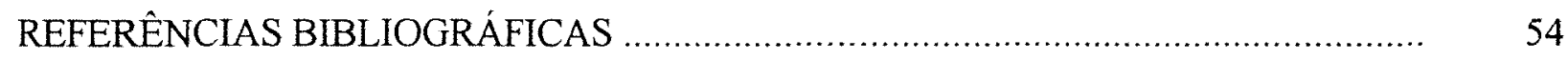




\section{LISTA DE FIGURAS}

Página

1. Teores foliares de cobre encontrados em três épocas de amostragem (prévia, 30 e 60 dias após a aplicação) nos tratamentos da área 1

2. Teores foliares de ,manganês encontrados em três épocas de amostragem (prévia, $30 \mathrm{e}$ 60 dias após a aplicação) nos tratamentos da área 1

3. Fórmula estrutural do mancozeb (produto de coordenação iônica de etilenobisditiocarbamato de manganês com íon zinco)

4. Teores foliares de zinco encontrados nos períodos de amostragem (prévia, 30 e 60 dias após a aplicação) na testemunha da área 1

5. Teores foliares de zinco encontrados em três épocas de amostragem (prévia, 30 e 60 dias após a aplicação) nos tratamentos da área 1

6. Teores foliares de boro encontrados em três épocas de amostragem (prévia, 30 e 60 dias após a aplicação) nos tratamentos da área 1

7. Média dos teores foliares de nitrogênio encontrados nos períodos de amostragem (prévia, 30 e 60 dias após a aplicação) na área 2.

8. Média dos teores foliares de fósforo encontrados nos períodos de amostragem (prévia, 30 e 60 dias após a aplicação) na área 2

9. Média dos teores foliares de potássio encontrados nos períodos de amostragem (prévia, 30 e 60 dias após a aplicação) na área 2 .

10. Média dos teores foliares de cálcio encontrados nos períodos de amostragem (prévia, 30 e 60 dias após a aplicação) na área 2

11. Média dos teores foliares de magnésio nos períodos de amostragem (prévia, 30 e 60 dias após a aplicação), na área 2

12. Média dos teores foliares de enxofre nos períodos de amostragem (prévia, 30 e 60 dias após a aplicação), na área 2

13. Teores foliares de cobre encontrados em três épocas de amostragem (prévia, 30 e 60 dias após a aplicação) nos tratamentos da área 2 
14. Teores foliares de manganês encontrados em três épocas de amostragem (prévia, 30 e 60 dias após a aplicação) nos tratamentos da área 2

15. Teores foliares de zinco encontrados nos períodos de amostragem (prévia, 30 e 60 dias após a aplicação), na testemunha da área 2

16. Teores foliares de zinco encontrados em três épocas de amostragem (prévia, 30 e 60 dias após a aplicação) nos tratamentos da área 2

17. Teores foliares de boro encontradso em três épocas de amostragem (prévia, 30 e 60 dias após a aplicação) nos tratamentos da área 2 


\section{LISTA DE TABELAS}

Página

1. Precipitação pluviométrica na Fazenda Niagara no período experimental ..................... 15

2. Resultados de análises químicas do solo da área experimental ................................. 16

3. Esquema de análise de variància (área 1) ..................................................... 17

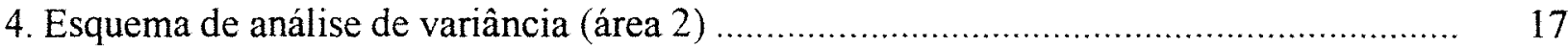

5. Esquema dos tratamentos, seus respectivos produtos e doses aplicadas na área 1 ......... 18

6. Esquema dos tratamentos, seus respectivos produtos e doses aplicadas na área $2 \ldots \ldots \ldots . . \quad 19$

7. Garantias mínimas e dosagens utilizadas de nutrientes (sais e quelados) em

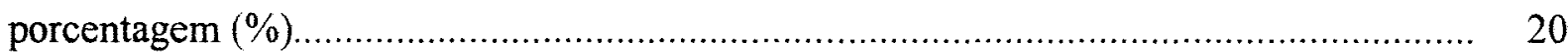

8. Teores de micronutrientes garantidos pelo fabricante nos fungicidas utilizados ............ 21

9. Porcentagem de micronutrientes no tanque, fornecido pelo fungicida, e a dosagem utilizada .....

10. Adubação realizada nas duas áreas durante o período experimental ........................... 22

11. Faixas para interpretação de teores de macro e micronutrientes nas folhas de citros, geradas na primavera, com 6 meses de idade

12. Teores foliares de $\mathrm{Cu}, \mathrm{Mn}, \mathrm{Zn}$ e B encontrados imediantamente antes da aplicação na área 1

13. Teores foliares de $\mathrm{Cu}, \mathrm{Mn}, \mathrm{Zn}$ e $\mathrm{B}$ encontrados 30 dias após a aplicação na área 1 ....... 26

14. Teores foliares de $\mathrm{Cu}, \mathrm{Mn}, \mathrm{Zn}$ e $\mathrm{B}$ encontrados 60 dias após a aplicação na área 1 ....... 27

15. Teores foliares de $\mathrm{N}, \mathrm{P}, \mathrm{K}, \mathrm{Ca}, \mathrm{Mg}$ e $\mathrm{S}$ encontrados imediatamente antes da aplicação na área 2

16. Teores foliares de $\mathrm{N}, \mathrm{P}, \mathrm{K}, \mathrm{Ca}, \mathrm{Mg}$ e $\mathrm{S}$ encontrados aos 30 dias após a aplicação na área 2

17. Teores foliares de $\mathrm{N}, \mathrm{P}, \mathrm{K}, \mathrm{Ca}, \mathrm{Mg}$ e $\mathrm{S}$ encontrados aos 60 dias após a aplicação na área 2

18. Teores foliares de $\mathrm{Cu}, \mathrm{Mn}, \mathrm{Zn}$ e $\mathrm{B}$ encontrados imediatamente antes da aplicação na área 2 
19. Teores foliares de $\mathrm{Cu}, \mathrm{Mn}, \mathrm{Zn}$ e B encontrados aos 30 dias após a aplicação na área 2 ..

20. Teores foliares de $\mathrm{Cu}, \mathrm{Mn}, \mathrm{Zn}$ e $\mathrm{B}$ encontrados aos 60 dias após a aplicação na área 2 


\title{
AVALIAÇÃO DOS TEORES FOLIARES DE MICRONUTRIENTES EM CITROS EM FUNÇÃO DA APLICAÇ̃̃O DE FUNGICIDAS, SAIS E QUELATIZADOS
}

\author{
Autor: Marcelo Melarato Silva \\ Orientador: Prof. Dr. Godofredo Cesar Vitti
}

RESUMO

Com exceção ao $\mathrm{B}$ a melhor maneira e mais usual de fornecer os micronutrientes $\mathrm{Zn}, \mathrm{Mn}$ e $\mathrm{Cu}$ na cultura dos citros é através da aplicação foliar, a qual, via-deregra, está associada às pulverizações fitossanitárias, visando aumentar a eficiência operacional.

O objetivo deste trabalho foi avaliar o estado nutricional das plantas em função do fornecimento destes micronutrientes na forma de sais e quelados, associados a fungicidas, além de estabelecer um grau de compatibilidade entre eles.

Foram conduzidos dois experimentos em condições de campo com plantas de citros variedade Pera-Rio (Citrus sinnensis L. Osbeck) enxertadas sobre limoeiro cravo (Citrus limonia L. Osbeck) as quais receberam, por ocasião da florada, pulverização de micronutrientes na forma de sais ou quelados, associados com diversos tipos de fungicidas normalmente usadas neste período. Foram avaliados os teores foliares de nutrientes imediatamente antes da aplicação e 30 e 60 dias após.

Todos os fungicidas cúpricos elevaram os teores foliares de $\mathrm{Cu}$ na seguinte ordem decrescente: oxicloreto de cobre $(0,20 \%)$, óxido cuproso $(0,15 \%)$ e hidróxido de cobre $(0,085 \%)$. A aplicação de benomyl $(0,05 \%)$ associado com $\mathrm{MnSO}_{4}(0,2 \%)$ e $\mathrm{ZnSO}_{4}(0,3 \%)$ resultou nos maiores teores foliares de $\mathrm{Mn}$ e $\mathrm{Zn}$ encontrados após 30 dias. 
A aplicação de fungicidas cúpricos, principalmente o óxido cuproso $(0,15 \%)$, associados com $\mathrm{MnSO}_{4}(0,20 \%)$ e $\mathrm{ZnSO}_{4}(0,30 \%)$, reduziu a concentração foliar de $\mathrm{Mn}$ e $\mathrm{Zn}$ o mesmo não acontecendo quando o fornecimento foi na forma de quelados. A aplicação do fungicida mancozeb $(0,20 \%)$ elevou e manteve adequado a concentração foliar de Mn durante os 60 dias.

O fornecimento de $\mathrm{Mn}$ e $\mathrm{Zn}$ na forma de quelados apresentou eficiência relativa maior do que os sais de sulfato, em relação a quantidade aplicada, na ordem de 10:1 e 8:1, respectivamente. Os teores de $\mathrm{Mn}$ e $\mathrm{Zn}$ reduziram-se sensivelmente após 30 e 60 dias da florada, atingindo a deficiência na ausência de suplementação. 


\title{
EVALUATION OF MICRONUTIENTS FOLIAR CONTENTS IN CITRUS AS A FUNCTION OF FUNGICIDES, SALTS AND CHELATES APPLICATION
}

\author{
Author: Marcelo Melarato Silva \\ Advisor: Dr. Godofredo Cesar Vitti
}

\section{SUMMARY}

Excepting B, the best and most usual way to supply the micronutrients $\mathrm{Zn}, \mathrm{Mn}$ and $\mathrm{Cu}$ in citrus is by leaf applications, which is associated to fitossanitary pulverization, aiming to increase the operational efficiency.

The objective of this study was to evaluate the nutritional status of citrus plants as a function of the supply of these micronutrients in the form of salts and chelates, associated to fungicides, and to establish the compatibility between them.

Two field experiments were conducted with citrus plants of the Pera-Rio (Citrus sinensis L. Osbeck) variety grafted on limoeiro cravo (Citrus limonia L. Osbeck) rootstock which received, during the flowering period, micronutrient pulverization in the form of salts and chelates, associated to various types of fungicides of normal use. The leaf nutrient contents were evaluated immediately before, 30 and 60 days after the application.

All the cupric fungicides increased the leaf contents of $\mathrm{Cu}$ in the following decreasing order: $0.2 \%$ of copper oxichloride application, $0.15 \%$ of cupric oxide, and $0.085 \%$ copper hidroxide. The application of benomyl $(0.05 \%)$ associated with $\mathrm{MnSO}_{4}(0.2 \%)$ and $\mathrm{ZnSO}_{4}(0.3 \%)$ resulted in higher leaf contents of $\mathrm{Mn}$ and $\mathrm{Fe}$ after 30 days.

The application of cupric fungicides, mainly cupric oxide $(0.15 \%)$, associated with $\mathrm{MnSO}_{4}(0.20 \%)$ and $\mathrm{ZnSO}_{4}(0.30 \%)$, reduced the leaf contents of $\mathrm{Mn}$ and $\mathrm{Zn}$. This was not observed when applied in the form of chelates. The application of mancozeb fungicide $(0.20 \%)$ increased and maintained the leaf contents of $\mathrm{Mn}$ in adequate levels for 60 days. 
The supply of $\mathrm{Mn}$ and $\mathrm{Zn}$ in the form of chelates in relation to sulfate salts in a rate of 1:10 and 1:8 presented the same efficiency. The contents of Mn and $\mathrm{Zn}$ were extremely reduced 30 and 60 days after flowering, reaching deficiency with the lack of supplementation. 


\section{INTRODUÇÃO}

Na cultura dos citros a aplicação de micronutrientes via foliar é uma prática fundamental pois possibilita rápida correção da deficiência, complementa o fornecimento de nutrientes e pode melhorar a qualidade dos frutos.

Nas condições brasileiras, devido ao tipo de solo onde os citros são normalmente cultivados e das variedades de copa e porta-enxerto utilizadas, os micronutrientes manganês, zinco e boro necessitam ser constantemente aplicados para manter os níveis adequados na planta.

A deficiência de cobre, dificilmente encontrada nas regiões citrícolas tradicionais do Estado de São Paulo, tem se manifestado com uma certa frequência principalmente na variedade Westin e em regiões de solos muito pobres onde a cultura dos citros vem se instalando atualmente.

Quanto ao fornecimento, com exceção do boro, a melhor maneira e mais usual para suprir esses micronutrientes é através da aplicação foliar.

As aplicações foliares de micronutrientes, via-de-regra, são associadas a pulverizações fitossanitárias visando aumentar a eficiência operacional. Esta é uma prática usual e bastante difundida entre os citricultores.

A pulverização de florada, ocasião em que normalmente realizam-se aplicações de fungicidas, é a primeira e uma das principais oportunidades para a inclusão de micronutrientes.

Dentre os fungicidas normalmente utilizados destacam-se os cúpricos que além do seu efeito fitossanitário são fontes de cobre à planta (micronutriente essencial).

A utilização de micronutrientes quelatizados vem ganhando espaço na citricultura brasileira. O motivo deste crescimento deve-se, principalmente, ao menor custo 
do produto além da facilidade de manipulação que estes produtos oferecem seja pelo menor volume necessário ou pela versatilidade na obtenção de misturas.

Sendo assim, torna-se cada vez mais importante o conhecimento das interações ocorridas entre os elementos nas diversas misturas utilizadas nas pulverizações e suas relações com o estado nutricional das plantas, visando maximizar a eficiência da adubação foliar.

Este trabalho teve como objetivos:

- Avaliar o estado nutricional das plantas de citros, principalmente em relação aos nutrientes cobre, manganês, zinco e boro em função do uso associado com fungicidas;

- Estabelecer ordem de compatibilidade entre os fungicidas testados levando-se em consideração o teor e relações foliares dos nutrientes;

- Dentre os tratamentos avaliados, definir a melhor combinação entre fontes de fungicidas e sais e, entre fungicidas e quelados;

- Observar se o fornecimento de micronutrientes na forma quelatizada interfere no grau de compatibilidade entre estes, e os fungicidas; 


\section{REVISÃO DE LITERATURA}

Se os fatores de produção fossem representados em forma de uma pirâmide, na base da mesma estaria o solo. Isso equivale a dizer que a nutrição é um do principais fatores de produtividade, através do qual conseguem-se altas respostas de produtividade com menores investimentos.

A nutrição dos citros, como observou Rodriguez (1991), constitui, na vida útil dos pomares, um dos fatores mais importantes para o seu bom desenvolvimento e para produção de fartas colheitas com frutos de melhor qualidade. No entanto, não se deve esquecer que a adubação começa com a análise de solo, continua com a correção da acidez e termina com a aplicação do adubo (Malavolta et al., 1989).

Malavolta \& Violante Netto (1989) afirmaram que a aplicação foliar de nutrientes quando comparada com a tradicional, via solo, é um "atalho" para alimentar a planta, uma vez que os nutrientes são fornecidos diretamente para a planta.Os fins principais dessa prática são: correção mais rápida de deficiências, complementação de adubação feita no solo e melhoramento da qualidade do produto agrícola.

Os citros são culturas que mais recebem adubo foliar no país, geralmente como micronutrientes ( $\mathrm{B}, \mathrm{Cu}, \mathrm{Mn}$ e $\mathrm{Zn}$ ). $\mathrm{E}$ isto se deve ao fato de que, quando usados os defensivos para o controle de pragas e moléstias, vários nutrientes são adicionados à suspensão ou à solução fazendo com que os custos desta operação seja reduzido. 


\subsection{Funções e exigências de cobre, manganês, zinco e boro}

\subsubsection{Funções do cobre}

As principais funções do cobre foram descritas por Dechen et al. (1991b): tendo participação nos seguintes processos fisiológicos : fotossíntese, respiração, distribuição de carboidratos, redução e fixação de nitrogênio, metabolismo de proteínas e da parede celular; influência na permeabilidade dos vasos do xilema à água; controle da produção de DNA e RNA, sendo que em deficiência severa inibe a reprodução das plantas (reduz a produção de sementes e apresenta pólen estéril); ocorre em compostos com funções não tão bem conhecidas como as das enzimas de vital importância no metabolismo de plantas; está envolvido em mecanismos de resistência à doenças. A resistência de plantas a doenças fúngicas está relacionado com o suprimento adequado de cobre.

\subsubsection{Funções do manganês}

Malavolta (1976) observou que o manganês é ativador de muitas enzimas de óxido-redução, descarboxilases, hidrolases, transferidoras de grupos (de radicais fosfatados de ATP, por exemplo).

Há uma proteína nas plantas chamada manganina, que contém manganês (Malavolta, 1976 e Dechen et al., 1991b).

A função mais estudada do manganês em plantas refere-se à sua participação no desdobramento da molécula de água e na evolução do $\mathrm{O}_{2}$ no sistema fotossintético (Dechen et al., 1991b). Há uma alta concentração de manganês nos cloroplastos (Malavolta, 1976).

Malavolta et al. (1989) citam que o manganês participa dos processos de absorção iônica, fotossíntese, respiração, controle hormonal e síntese de proteínas. 


\subsubsection{Funções do zinco}

O zinco atua nos processos de respiração, controle hormonal e síntese de proteínas (Malavolta et al., 1989).

A participação mais importante do zinco nos processos metabólicos das plantas é como componente de várias enzimas, tais como: desidrogenases, proteinases, peptidases e fosfohidrolases (Dechen et al., 1991b).

Há provas de que o $\mathrm{Zn}$ é ativador do triptofano o qual é sabidamente o ponto de partida para a sintese do ácido indolacético (AIA) uma auxina promotora de crescimento (Malavolta, 1976). Logo as células deficientes em $\mathrm{Zn}$ produzem menos AIA, isto é, menor tamanho das células ocasionando encurtamento dos internódios, redução do tamanho de novas brotações e das folhas (Vitti, 1992).

\subsubsection{Funções do boro}

A função fisiológica do boro difere da dos outros micronutrientes pois, conforme relataram Dechen et al. (1991b), este ânion não foi identificado em nenhum composto ou enzimas específicas.

O boro participa dos processos de absorção iônica e transporte de carboidrato além da síntese de ácidos nucleicos, proteínas, lignina e celulose (Malavolta et al., 1989).

Malavolta \& Violante Netto (1989) sugeriram também os papéis funcionais do boro no florescimento e expressão sexual; germinação de grão de pólen e crescimento do tubo polínico; ativação do zinco e elongação celular.

\subsubsection{Exigências de cobre, manganês, zinco e boro}

Embora a absorção mineral dos citros ocorra durante todo o ano, ela é maior no florescimento e quando se formam folhas e ramos novos nos períodos de setembro a dezembro e março a abril no hemisfério sul (Kampfer \& Uexkull, 1963). 
Resultados de Marchal \& Lacoeuilhe', citados por Malavolta (1979) mostraram que do total contido na planta a exportação pelos frutos representa $20 \%$ para $\mathrm{Cu}, 15 \%$ para $\mathrm{Mn}, 20 \%$ para $\mathrm{Zn}$ e $25 \%$ para B.

Em relação à exportação Bataglia et al. (1977) apresentaram para a variedade Pera, valores exportados para uma tonelada de frutos produzidos $(15.700 \mathrm{~g}$ de matéria seca) de $0,6 \mathrm{~g}$ de $\mathrm{Cu}, 0,9 \mathrm{~g}$ de $\mathrm{Mn}, 0,7 \mathrm{~g}$ de $\mathrm{Zn}$ e 2,4 $\mathrm{g}$ de B, podendo-se estabelecer a seguinte ordem de exportação: $\mathrm{B}>\mathrm{Mn}>\mathrm{Zn}>\mathrm{Cu}$ para a variedade Pera.

\subsection{Avaliação do estado nutricional}

\subsubsection{Diagnose visual}

\subsubsection{Sintomas de deficiência de Cobre}

Vários autores descreveram os sintomas de deficiência de cobre na cultura dos citros: Reitz (1958a); Kampfer \& Uexkull (1963); Malavolta (1976); Rodriguez (1979); Malavolta \& Violante Netto (1989); Du Plessis (1992), entre outros.

$\mathrm{Na}$ deficiência de cobre aparecem, inicialmente, folhas verdes escuras de tamanho exagerado, dando a impressão de tratar-se de excesso de nitrogênio. Ocorre também, a morte descendente dos ramos ("dieback"), podendo ocorrer bolsa de goma nos ramos novos e crescimento dos ramos em forma de "S".

Os sintomas nos frutos apresentam-se como manchas marrons e áreas encharcadas de goma de formas irregulares. Frutos provenientes de árvores deficientes de cobre são indesejáveis devido à baixa acidez do suco e ao baixo conteúdo de suco da fruta.

Outros sintomas nos frutos são a presença de goma na casca e ao redor das sementes, sintomas não muito confiáveis, segundo Reitz (1958a), por assemelhar-se a deficiência de boro.

\footnotetext{
${ }^{1}$ MARCHAL, J. \& LACOEUILHE, J.J. Bilan mineral des mandarines "Wiking". Fruits.24(6):299-318, 1969.
} 


\subsubsection{Sintomas de deficiência de manganês}

Os sintomas de deficiència de manganès aparecem tanto nas folhas novas como nas maduras sem afetar o tamanho das mesmas (Kampfer \& Uexkull, 1963).

Malavolta \& Violante Netto (1989) descreveram a deficiência de manganês como sendo uma "malha" verde pálida na folha toda, a qual pode ter formato de "ferradura" com a parte aberta voltada para a nervura principal ou pode mostrar-se como um reticulado grosso (as nervuras e uma faixa de tecido ao longo das mesmas permanecem verdes).

Em casos menos severos (Reitz, 1958b) os sintomas aparecem nos novos lançamentos e desaparecem durante a vida da folha, com o escurecimento de área verde clara. Nos casos mais severos as áreas verdes claras permanecem a vida inteira.

\subsubsection{Sintomas de deficiência de zinco}

A deficiência de zinco em citros é muito comum nas folhas e plantas novas segundo Du Plessis $(1988)^{2}$ citado por Du Plessis (1992).

Kampfer \& Uexkull (1963) descreveram que no início da ocorrência desta deficiência aparecem manchas cloróticas e irregulares entre as nervuras das folhas, as quais permanecem verdes.

Em casos severos, segundo Leonard \& Stewart (1958), as folhas tornam-se frequentemente muito pequenas e estreitas com pontas finas podendo ocorrer morte descendente dos ramos.

Dechen et al. (1991a) resumiram a deficiência de zinco para citros como sendo a presença de internódios curtos, folhas novas estreitas (lanceoladas) e com cor amarelada entre as nervuras.

\footnotetext{
${ }^{2}$ Du PLESSIS, S.F. Micro elements in citrus. Farming in South Africa, E.5, 1988.
} 


\subsubsection{Sintomas de deficiência de boro}

Segundo Vitti (1992) os principais efeitos do boro em citros estão relacionados ao tamanho e qualidade dos frutos. Os sintomas de deficiência aparecem em orgãos mais novos devido a sua baixa mobilidade no floema.

A queda de frutos é excessiva e os frutos defícientes em boro são geralmente "empelotados", mal formados e com a casca dura e espessa segundo observou Deszyck (1958). Os frutos apresentam-se com muito albedo com goma perto da pele ou também nos lóculos. As sementes também podem abortar (Malavolta \& Violante Netto, 1989).

Plantas deficientes em boro apresentam desenvolvimento reduzido e as vezes secamento das estremidades dos ramos. As folhas tornam-se menores, com ondulações no limbo e com nervuras salientes, muitas vezes "corticosas", nos casos mais severos (Rodriguez, 1991).

\subsubsection{Análise de solo}

Normalmente não é utilizada a análise de solo para recomendação de micronutrientes. Malavolta \& Violante Netto (1989) apresentaram como sugestão, 15g de zinco/caixa quando o teor no solo for menor do que $1 \mathrm{ppm} ; 7,5 \mathrm{~g}$ de $\mathrm{Zn} /$ caixa quando o teor no solo estiver entre 1 e 2 ppm e dispensa o fornecimento de $\mathrm{Zn}$, quando o teor no solo for $>2$ ppm (extrator, duplo ácido).

Como interpretação preliminar de resultados de análise de solo para micronutrientes o Grupo Paulista de Adubação e Calagem para Citros-GPACC (1994) apresentou como classes de teores baixo, médio e alto, respectivamente, expressos em $\mathrm{mg} / \mathrm{dm}^{3}$, o seguinte: boro $(<0,20 ; 0,20-0,60 \mathrm{e}>0,60)$, cobre $(<0,30 ; 0,30-1,0$ e $>1,0)$, manganês $(<1,5 ; 1,5-5,0 \mathrm{e}>5,0)$ e zinco $(<0,7 ; 0,7-1,5 \mathrm{e}>1,5)$. 


\subsubsection{Diagnose foliar}

A análise de folhas é atualmente uma das melhores técnicas disponiveis para avaliar o estado nutricional dos pomares e orientar programas de adubação (Rodriguez, 1991) junto com conhecimento da fertilidade do solo e influências de outros fatores.

A diagnose foliar é um método de avaliação do estado nutricional das culturas em que se analisam determinadas folhas em períodos definidos da vida da planta. O motivo pelo qual analisam-se as folhas é conhecido: elas são os órgãos que, como regra geral, refletem melhor o estado nutricional, isto é, respondem mais às variações no suprimento de nutrientes, seja pelo solo, seja pelo adubo (Malavolta et al., 1989).

Koo (1979) observou que as tendências da composição mineral das folhas, ao longo de um período de anos, podem determinar se o suprimento dos elementos nutricionais é inadequado, satisfatório ou desnecessariamente alto. Isto permitirá a adoção de medidas corretivas em tempo, antes que se desenvolvam quadros de deficiências ou excesso.

Segundo as recomendações de amostragem foliar (Vitti, 1988), tomando por base as folhas extraídas de ramos frutíferos, de fluxo de primavera, 3 a 7 meses de idade e sendo a terceira folha após o fruto, são considerados como adequados os teores foliares, de 4,1 a $10 \mathrm{mg} / \mathrm{kg}$ para cobre, 35 a $50 \mathrm{mg} / \mathrm{kg}$ para manganês, 35 a $50 \mathrm{mg} / \mathrm{kg}$ para zinco e 36 a $100 \mathrm{mg} / \mathrm{kg}$ para boro (Malavolta \& Violante Netto, 1989; Rodriguez, 1991; GPACC, 1994).

\subsection{Causas da deficiência ou excesso de Cobre, Manganês, Zinco e Boro}

\subsubsection{Cobre}

Reitz (1958a) apresentou a falta de disponibilidade de cobre no solo como a principal causa da deficiência, nas áreas cultivadas com citros nos Estados Unidos.

Nas condições brasileiras, além da pobreza no solo (solos arenosos), a calagem excessiva e o excesso de matéria orgânica são as principais causas de deficiência de cobre (Malavolta et al., 1989) uma vez que a elevação do $\mathrm{pH}$ diminui a disponibilidade 
do elemento para as plantas e no segundo caso devido a formação de complexos estáveis com o cobre (Ferreira \& Cruz, 1991).

Malavolta (1976) apresentou a possibilidade de uma diluição no teor de cobre do tecido em consequência da adubação nitrogenada.

Em pomares em que é comum o combate de fungos com produtos à base de cobre não é comum a ocorrência desta deficiência (Rodriguez, 1991).

O excesso de $\mathrm{Cu}$ em geral está relacionado com a utilização excessiva de defensivos (Malavolta et al., 1989 e Alva et al., 1993).

O porta-enxerto pode influenciar o teor de cobre nas folhas. Fallahi et al. (1991) encontraram maior teor deste elemento em Tangelo Orlando quando este foi enxertado sobre Citrange Carrizo.

O problema de deficiência de cobre também pode estar relacionado com a variedade de copa. Vitti (1992) observou ocorrência deste problema na variedade Westin.

Quando há toxidez de cobre, as folhas caem facilmente, em geral mostrando clorose nas nervuras, seguido de manchas aquosas internervais, a casca se racha e mostra goma, há morte de raizes (Malavolta \& Violante Netto, 1989).

\subsubsection{Manganês}

A deficiência de manganês em consequência da pobreza no solo é rara nas condições brasileiras (Malavolta, 1976), ao contrário das condições da Flórida, nos EUA, onde pode ocorrer baixos teores no solo e também devido ao alto $\mathrm{pH}$ (Reitz, 1958b).

A calagem excessiva, o excesso de matéria orgânica, e excesso de adubação fosfatada podem levar à falta de manganês (Malavolta et al., 1989).

A carência de manganês em solos ácidos em geral está associada com as deficiências de magnésio, cobre e zinco (Malavolta \& Violante Netto, 1989). No Brasil, raros são os pomares em que haja somente deficiência de manganês dissociada da de zinco.

A maior parte da área cultivada no Sul e no Leste do país está sobre solos derivados de rochas eruptivas básicas, ricas em manganês, porém em solos formados a partir de arenitos nem sempre este elemento é disponível em teores elevados (Borkert, 1991). 
A principal causa de toxidez de manganês é a acidez do solo seja natural ou provocada pelo fertilizante, bem como à pouca aeração ( compactação ou encharcamento).

O sintoma foliar mais característico da toxidez de manganês é o amarelecimento da margens das folhas, cuja porção central permanece verde, lembrando a carência de cálcio (Malavolta \& Violante Netto, 1989). Em casos agudos aparecem manchas necróticas em várias partes do limbo, provavelmente devido ao acúmulo local de óxidos de manganês. $\mathrm{O}$ excesso de manganès é corrigido mediante o aumento na aeração do solo e pela aplicação de calcário.

\subsubsection{Zinco}

O zinco parece ser o problema mais grave entre os micronutrientes em plantas cítricas no Brasil (Souza \& Ferreira, 1991).

Hiroce \& Caetano (1984), apresentaram duas hipóteses para a incidência de deficiência de zinco de forma (bastante elevada): a primeira está ligada à eficiência real do fornecimento de zinco por via foliar ou ao número de aplicações e a segunda seria a presença de vírus que limitaria a absorção do elemento e sua translocação nas folhas.

A pobreza no solo, calagem e adubação fosfatada excessivas são fatores que levam à deficiência de zinco (Malavolta et al., 1989) além de excesso de nitrogênio. Em solos derivados de granito e gnaisses a deficiência é mais comum, segundo Malavolta \& Violante Netto (1989), que descreveram os principais sintomas de toxidez que correspondem a queima das folhas, desfolhamento e morte descendentes de ramos e clorose semelhante a falta de ferro. Os teores de zinco nas folhas encontram-se, neste caso, acima de $100 \mathrm{mg} / \mathrm{kg}$.

O tipo de porta-enxerto pode influenciar os teores de zinco na folha. Os maiores teores em pomelo ("grapefruit") foram encontrados quando estas foram enxertadas sobre limão Volkameriano enquanto que Citromelo Swingle apresentou teores menores (Fallahi, 1992). 


\subsubsection{Boro}

O boro é um elemento cuja deficiência ocorre de forma generalizada nos pomares brasileiros (Vitti, 1992).

A pobreza no solo (pouca matéria orgânica), a acidez excessiva e a lixiviação são as principais causas da deficiência de boro nas condições brasileiras, enquanto que, a toxidez, geralmente, é função do excesso na adubação (Malavolta et al., 1989).

Os sintomas do excesso de boro nos citros foram descritos por Malavolta \& Violante Netto (1989). As folhas amarelecem nas pontas e margens e em seguida entre as nervuras, dando uma clorose malhada. Em seguida aparecem pontuações ou pequenas áreas necróticas no limbo ou na margem. Pode ocorrer queda de folhas.

Segundo Deszyck (1958) existem nos citros variações na capacidade de absorção do boro pelo porta-enxerto utilizado.

\subsection{Interações e respostas a Cobre, Manganês, Zinco e Boro}

$\mathrm{O}$ conhecimento de fatores que influenciam na absorção foliar são fundamentais, principalmente, no tocante à aplicação de nutrientes isolados ou conjuntamente com defensivos agrícolas.Assim, podem ocorrer casos de antagonismo, inibição e sinergismo.

A presença de cobre ou boro reduz a absorção de zinco. No primeiro caso (cobre $\mathrm{x}$ zinco), trata-se de inibição competitiva que pode ser atenuada aumentando-se a concentração de zinco na solução, enquanto que, no segundo caso (boro x zinco), trata-se de inibição não-competitiva, isto é, os elementos envolvidos são transportados por carregadores diferentes (Vitti, 1992). Assim, para evitar esta competição a maneira clássica seria a aplicação separada desses elementos. Entretanto, isto torna-se inviável do ponto de vista econômico. Para contornar este problema é sugerida na literatura a adição de produtos, como uréia e cloreto de potássio (GPACC,1994), que aumenta a velocidade de absorção do elemento em desvantagem. 
Steyn \& Eve (1956) observaram redução na absorção de zinco em citros diminuida pelo cobre (uréia + zinco + cobre $=6 \mathrm{mg} / \mathrm{kg}$ de zinco nas folhas) e favorecida pela uréia (uréia + zinco $=56 \mathrm{mg} / \mathrm{kg}$ de zinco).

Swietlik \& La Duke (1991) observaram em vários ensaios de campo com laranjeiras, que a aplicação de sulfato de zinco isolado, promove diminuição nos teores de manganès sem no entanto atingir o nivel de deficiente.

Mann \& Takkan (1983), em ensaios conduzidos em vasos com laranja doce, encontraram um antagonismo mútuo entre cobre e zinco para suas absorções na superfície da folha quando os mesmos foram aplicados na forma de sulfato de cobre e sulfato de zinco. Neste trabalho também foi encontrado antagonismo entre sulfato de manganês e sulfato de zinco.

Constatou-se aumento no teor de sólidos solúveis quando foi usado zinco e mistura de zinco e cobre enquanto que o teor de vitamina $C$ aumentou no tratamento zinco e cobre e cobre isolado em frutas de laranja após 2 anos de trabalho conduzido na India (Bacha, 1975).

\subsection{Quelados}

A palavra quelado vem do grego e quer dizer pinça ou garra. Na prática um micronutriente metálico, como $\mathrm{Cu}, \mathrm{Mn}$ e $\mathrm{Zn}$ pode ser mudado quimicamente pela formação de uma estrutura ao seu redor, ou seja, através de ligação covalente coordenada de um cátion bivalente, para dois átomos doadores do ligante aminoácido, para formar uma estrutura anelar heterocíclica, formando o agente quelante ou de quelação, o qual impede que reações indesejáveis com o elemento quelatizado tenham lugar na água, no solo ou na própria planta (Malavolta, 1994; Tisdale et al. 1985).

Segundo Tisdale et al. (1985) não se sabe ao certo como os quelados são absorvidos e utilizados pelas plantas.

A eficiência dos quelados em relação aos sais é bastante superior. Wallace $(1966)^{3}$ citado por Alvarez (1987), observou que as culturas necessitam receber 5 a 10

\footnotetext{
${ }^{3}$ WALLACE, A. Chelated metal for supplying micronutrients to fruit crops. In. Chelated growing plants. California. 1996
} 
vezes mais zinco quando se opta por um sal inorgânico em lugar de um quelado de zinco, ou seja os quelados de zinco são muito mais disponíveis por unidade de zinco do que as fontes inorgânicas. Da mesma forma Anderson $(1964)^{4}$ citado por Lindsay (1972) concluiu que fontes de quelados são geralmente muito mais efetivas em baixas quantidades quando comparados ao sulfato de zinco, necessitando de $1,12 \mathrm{~kg} \mathrm{Zn/ha} \mathrm{como} \mathrm{ZnEDTA} \mathrm{para} \mathrm{3,36kg}$ $\mathrm{Zn} / \mathrm{ha}$ como $\mathrm{ZnSO}_{4}$ no caso. de aplicação ao solo.

${ }^{4}$ ANDERSON, W.B. Fort Collins, 1964 (PhD). Thesis, Colorado State University. 


\section{MATERIAL E MÉTODOS}

Os experimentos foram conduzidos em condições de campo em duas áreas separadas porém próximas e nas mesmas condições edafoclimáticas.

\subsection{Local}

Os experimentos foram instalados na Fazenda Niagara, município de Araraquara, Estado de São Paulo, sendo o acesso através da Rodovia Nelson Barbieri, Km 15.

\subsection{Clima e solo}

Os dados de precipitação pluviométrica durante o período em que foram realizados o ensaio, encontram-se na Tabela 1.

Tabela 1 - Precipitação pluviométrica na Fazenda Niagara no período experimental.

\begin{tabular}{|c|cccccc|}
\hline \multirow{2}{*}{ Ano } & Set & Out & Nov & Dez & Jan \\
\hline \multirow{2}{*}{1993} & 105 & 59 & 214 & 290 & 363 \\
1994 & - & 155 & 234 & 270 & 373 \\
\hline
\end{tabular}

O solo da área experimental foi classificado como Latossolo Vermelho Escuro, cujas características químicas constam na tabela 2. 
Tabela 2. Resultados da análise química do solo da área experimental.

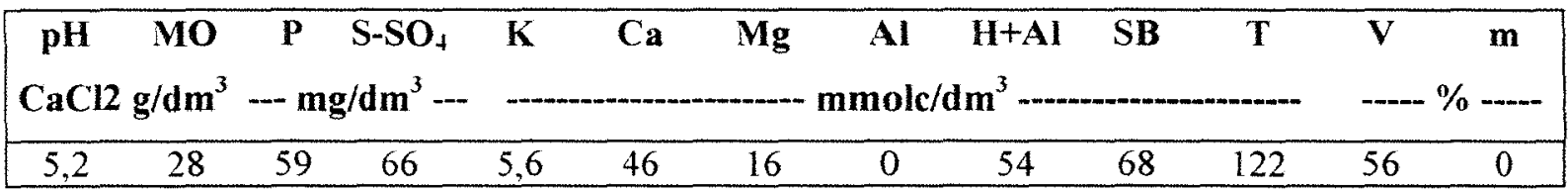

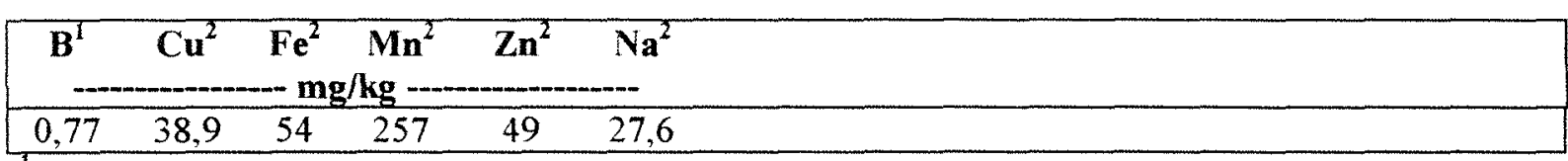

Extrator $\mathrm{BaCl}_{2} \mathbf{0 , 1 \%}$

${ }^{2}$ Extrator $\mathrm{HCl} 0,05 \mathrm{~N}+\mathrm{H}_{2} \mathrm{SO}_{4}, 0,025 \mathrm{~N}$

\subsection{Planta}

As duas áreas, onde se realizaram os experimentos, eram pomares de laranjeiras variedade Pera-Rio (Citrus sinnensis L. Osbeck), enxertadas sobre limoeiro Cravo (Citrus limonia L. Osbeck) sendo o pomar da primeira área (área 1) de 6 anos de idade e o da segunda área (área 2) de 9 anos.

\subsection{Delineamento experimental e tratamentos}

\subsubsection{Delineamento experimental}

$\mathrm{Na}$ área 1 o experimento foi instalado segundo um delineamento experimental em blocos casualizados, com 8 tratamentos e 5 repetições, totalizando 40 parcelas (Tabela 3).

$\mathrm{Na}$ área 2 o delineamento experimental também foi em blocos casualizados, com 9 tratamentos e 5 repetições, totalizando 45 parcelas (Tabela 4).

Nas duas áreas, as parcelas foram compostas cada uma de 5 plantas úteis espaçadas entre si por 3,5 $\mathrm{m}$ (na linha) e por 7,5 m nas entre-linhas. Cada parcela foi separada na linha por 4 plantas e na entre-linha por uma linha de laranjeiras (bordaduras) para que se evitassem possíveis interferências por deriva de produtos durante a pulverização. 
Tabela 3. Esquema de análise de variância (área 1).

\begin{tabular}{|cc|}
\hline Causas de variacão (CV) & Graus de Liberdade (GL) \\
\hline Tratamentos & 7 \\
Blocos & 4 \\
Resíduo & 28 \\
\hline Total & 39 \\
\hline
\end{tabular}

Tabela 4. Esquema de análise de variância (área 2).

\begin{tabular}{|cc|}
\hline Causas da variacão $(\mathbf{C V})$ & Graus de Liberdade (GL) \\
\hline Tratamentos & 8 \\
Blocos & 4 \\
Resíduo & 32 \\
\hline Total & 44 \\
\hline
\end{tabular}

Os dados foram submetidos as análises de variância, segundo o delineamento em blocos casualizados, sem transformação das variáveis. A comparação das médias entre os tratamentos foi realizada através do teste de Tukey ao nível de 5\% de probabilidade. A análise estatística foi realizada no microcomputador através da utilização do programa SANEST.

\subsubsection{Tratamentos}

Nas Tabela 5 e 6 estão apresentados todos os tratamentos que foram realizados nas áreas 1 e 2 , respectivamente. 
Tabela 5. Esquema dos tratamentos, seus respectivos produtos e doses aplicadas na área 1.

\begin{tabular}{|c|c|c|c|c|c|c|}
\hline \multirow[t]{2}{*}{$\mathbf{N}^{\mathbf{0}}$} & \multirow[t]{2}{*}{ TRATAMENTOS } & \multirow{2}{*}{$\begin{array}{c}\text { DOSE } \\
\mathrm{kg} / 2000 \mathrm{~L}\end{array}$} & $\mathbf{B}$ & $\mathrm{Cu}$ & $\mathbf{Z n}$ & Mn \\
\hline & & & \multicolumn{4}{|c|}{ 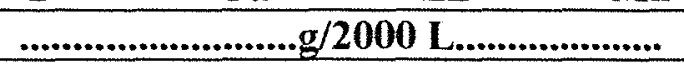 } \\
\hline \multirow[t]{3}{*}{1} & Mancozeb $80 \%$ & 4,0 & & & & \\
\hline & Ácido bórico & 1,0 & & & & \\
\hline & & & 170 & & 80 & 640 \\
\hline \multirow[t]{4}{*}{2} & Mancozeb $80 \%$ & 4,0 & & & & \\
\hline & Sulfato de zinco & 5,64 & & & & \\
\hline & Ácido bórico & 1,0 & & & & \\
\hline & & & 170 & & 1320 & 640 \\
\hline \multirow[t]{4}{*}{3} & Mancozeb $80 \%$ & 4,0 & & & & \\
\hline & Sulfato de manganês & 1,63 & & & & \\
\hline & Ácido bórico & 1,0 & & & & \\
\hline & & & 170 & & 80 & 1080 \\
\hline \multirow[t]{5}{*}{4} & Mancozeb 80\% & 4,0 & & & & \\
\hline & Sulfato de zinco & 5,64 & & & & \\
\hline & Sulfato de manganês & 1,63 & & & & \\
\hline & Ácido bórico & 1,0 & & & & \\
\hline & & & 170 & & 1320 & 1080 \\
\hline \multirow[t]{3}{*}{5} & Oxido cuproso & 3,0 & & & & \\
\hline & Ácido bórico & 1,0 & & & & \\
\hline & & & 170 & 1500 & & \\
\hline \multirow[t]{5}{*}{6} & Óxido cuproso & 3,0 & & & & \\
\hline & Sulfato de zinco & 6,0 & & & & \\
\hline & Sulfato de manganês & 4,0 & & & & \\
\hline & Ácido bórico & 1,0 & & & & \\
\hline & & & 170 & 1500 & 1320 & 1080 \\
\hline \multirow[t]{4}{*}{7} & Sulfato de zinco & 6,0 & & & & \\
\hline & Sulfato de manganês & 4,0 & & & & \\
\hline & Ácido bórico & 1,0 & & & & \\
\hline & & & 170 & & 1320 & 1080 \\
\hline
\end{tabular}


Tabela 6. Esquema dos tratamentos, seus respectivos produtos e doses aplicadas na área 2.

\begin{tabular}{|c|c|c|c|c|c|c|c|}
\hline \multirow[t]{2}{*}{$\mathrm{N}^{0}$} & \multirow[t]{2}{*}{ TRATAMENTO } & \multirow{2}{*}{$\begin{array}{c}\text { DOSE } \\
\mathrm{kg} / 2000 \mathrm{~L}\end{array}$} & $\mathrm{~N}$ & B & $\mathbf{C u}$ & $\mathrm{Zn}$ & $\mathrm{Mn}$ \\
\hline & & & \multicolumn{5}{|c|}{ 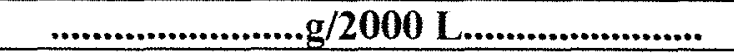 } \\
\hline \multirow[t]{3}{*}{1} & Oxicloreto de cobre & 4,0 & & & & & \\
\hline & M.S. & - & & & & & \\
\hline & & & 4400 & 170 & 2200 & 1320 & 1080 \\
\hline \multirow[t]{2}{*}{2} & Hidróxido de cobre & 1,7 & & & & & \\
\hline & 10.2 & - & 4400 & 170 & 1105 & 1320 & 1080 \\
\hline \multirow[t]{3}{*}{3} & Oxido cuproso & 3,0 & & & & & \\
\hline & M.S. & - & & & & & \\
\hline & & & 4400 & 170 & 1500 & 1320 & 1080 \\
\hline \multirow[t]{3}{*}{4} & Benomyl & 1,0 & & & & & \\
\hline & M.S. & - & & & & & \\
\hline & & & 4400 & 170 & & 1320 & 1080 \\
\hline \multirow[t]{2}{*}{5} & Oxicloreto de cobre & 4,0 & & & & & \\
\hline & IM. $Q$. & & 4400 & 100 & 2200 & 168 & 112 \\
\hline \multirow[t]{3}{*}{6} & Hidróxido de cobre & 1,7 & & & & & \\
\hline & M.Q. & - & & & & & \\
\hline & & & 4400 & 100 & 1105 & 168 & 112 \\
\hline \multirow[t]{2}{*}{7} & Oxido cuproso & 3,0 & & & & & \\
\hline & M.Q. & - & 4400 & 100 & 1500 & 168 & 112 \\
\hline \multirow[t]{2}{*}{8} & Benomyl & 1,0 & & & & & \\
\hline & M. & - & 4400 & 100 & & 168 & 112 \\
\hline 9 & Testemunha & $\pi$ & & & & & \\
\hline
\end{tabular}

Legenda: Doses para 2000 litros de solução.

M.S. = Mistura de Sais: Sulfato de zinco $6,0 \mathrm{~kg}$; Sulfato de manganès $4,0 \mathrm{~kg}$; Ácido bórico $1,0 \mathrm{~kg}$ e Uréia $10,0 \mathrm{~kg}$.

M.Q.= Mistura de Quelados: Ager zinco 0,8 L; Ager manganês 0,8 L; Ager boro 1,0 L e Uréia $10,0 \mathrm{~kg}$.

\subsection{Detalhamento dos tratamentos}

As dosagens utilizadas dos fungicidas foram aquelas recomendadas pelos fabricantes. 
Os micronutrientes utilizados seguiram as dosagens recomendadas pelo GPACC (1994), exceto para boro que teve sua dosagem reduzida por já ter sido aplicado via solo anteriormente ao experimento.

$\mathrm{Na}$ área 1, as doses de sulfato de zinco e de manganês foram reduzidas para descontar o Mn e $\mathrm{Zn}$ fornecidos pelo Mancozeb (Tabela 9).

A tabela 8 apresenta as garantias mínimas dos nutrientes utilizados fornecidos pelos fabricantes e as dosagens utilizadas.

Tabela 7. Garantias mínimas e dosagens utilizadas de nutrientes (sais e quelados) em porcentagem (\%).

\begin{tabular}{|cccccc|}
\hline Nutriente & N & Zn & Mn & B & $\begin{array}{c}\text { Dosagem } \\
\end{array}$ \\
\hline Uréia & 44 & - & - & - & 0,5 \\
Sulfato de Zn & - & 22 & - & - & 0,3 \\
Sulfato de Mn & - & - & 27 & - & 0,2 \\
Ácido Bórico & - & - & - & 17 & 0,05 \\
Ager Zn & - & 21 & - & - & 0,04 \\
Ager Mn & - & - & 14 & - & 0,04 \\
Ager B & - & - & - & 10 & 0,05 \\
\hline
\end{tabular}

Os produtos com os nomes comerciais Ager $\mathrm{Zn}$ e Ager Mn são micronutrientes quelatizados orgânicos (lignosulfanatos) formulados a partir das fontes químicas de cloreto de zinco e cloreto de manganês apresentando-se na forma de solução.

O produto Ager B é a base de boro formulado a partir da fonte química de éster (boro orgânico).

Os fungicidas utilizados apresentam modo de ação diferentes. A ação do benomyl é sistêmica, enquanto que o mancozeb e os cúpricos atuam por contato. Todos exercem, em maior ou menor grau, controle sobre o fungo da verrugose (Elsinoe australis Bit. e Jenk), sendo que o mancozeb apresenta também efeito sobre o ácaro da falsa ferrugem (Phyllocoptruta oleivora).

Além de controle fitossanitário alguns destes fungicidas apresentam em sua composição elementos que são nutrientes das plantas (Tabela 8 e 9). 
Tabela 8. Teores de micronutrientes garantidos pelo fabricante nos fungicidas utilizados.

\begin{tabular}{|ccccc|}
\hline Fungicida & Zn & Mn & Cu & Cl \\
\hline & 2 & 17 & - & - \\
Mancozeb & - & - & 50 & 0 \\
Oxido cuproso & - & - & 50 & 30 \\
Oxicloreto de cobre & - & - & 45 & - \\
Hidróxido de cobre & - & - & - & - \\
Benomyl & & & & \\
\hline
\end{tabular}

Tabela 9. Porcentagem de micronutrientes no tanque fornecido pelo fungicida e a dosagem utilizada.

\begin{tabular}{|ccccccc|}
\hline Fungicida & Zn & Mn & Cu & Cl & Dosagem \\
\hline & & & & & & \\
\hline Mancozeb & 0,004 & 0,034 & - & - & 0,20 \\
Óxido cuproso & - & - & 0,075 & - & 0,15 \\
Oxicloreto de cobre & - & - & 0,100 & 0,06 & 0,20 \\
Hidróxido de cobre & - & - & 0,038 & - & 0,085 \\
Benomyl & - & - & - & - & 0,05 \\
\hline
\end{tabular}

\subsection{Instalação e condução dos experimentos}

As áreas experimentais receberam os tratamentos fitossanitários usuais (exceto fungicidas) de tal forma que os produtos utilizados não fornecessem nutrientes às plantas para evitar interferências.

A adubação via solo para N, P e K foi conforme a tabela 10. Quanto a calagem, aplicou-se calcário dolomítico em quantidade suficiente para elevar a saturação por base a $70 \%$. Não foi fornecido nenhum micronutriente via solo durante a época do experimento. 
Tabela 10 - Adubação realizada nas duas áreas durante o período experimental.

\begin{tabular}{|cccc|}
\hline & Fórmula & $\begin{array}{c}\text { Dose } \\
\text { g/planta }\end{array}$ & $\begin{array}{c}\text { Data } \\
\text { Aplicação }\end{array}$ \\
\hline Área 1 & $15-05-10^{*}$ & 900 & $11 / 10$ \\
Área 2 & $12-06-12^{*}$ & 1500 & $22 / 11$ \\
\hline
\end{tabular}

* Fórmula com Nitrato de Amônio, Superfosfato Simples e Cloreto de Potássio

O controle das ervas invasoras foi realizado cuidadosamente, através de herbicida à base de glifosate, a fim de evitar concorrência com as plantas.

Os tratamentos foram aplicados por ocasião da florada quando dois terços das pétalas estavam caídas, a fim de atender a recomendação para o controle de verrugose (Elsinoe australis Bit e Jenk) feito pelos fungicidas testados e também por ser a época mais adequada para a $1^{a}$ adubação foliar (GPACC, 1994).

No caso da área 1 a aplicação foi feita no dia 22 de outubro de 1993, enquanto que na área 2 no dia 23 de novembro de 1994, devido ao início tardio das chuvas (Tabela 1) que resultou no atraso da florada naquele ano.

As aplicações foram feitas por equipamento tratorizado, utilizando-se de pistolas manuais para a pulverização. A cobertura foi aquela suficiente para molhar $100 \%$ da planta, principalmente na sua parte externa. Foram utilizados ao redor de 7 litros de calda por planta na área 1 e 10 litros na área 2.

\subsection{Avaliação dos experimentos}

A avaliação dos experimentos foi feita através da comparação dos níveis de nutrientes da folha (estado nutricional), usando como parâmetros para interpretação os teores apresentados na Tabela 11. (GPACC, 1994). 
Tabela 11. Faixas para interpretação de teores de macro e micronutrientes nas folhas de citros, geradas na primavera, com 6 meses de idade.

\begin{tabular}{|cccc|}
\hline Nutrientes & Baixo & Adequado & Excessivo \\
\hline $\mathrm{N}$ & $<23$ & $\mathbf{g} / \mathbf{k g}$ & $>30$ \\
$\mathrm{P}$ & $<1,2$ & $1,2-1,6$ & $>2,0$ \\
$\mathrm{~K}$ & $<10$ & $10-15$ & $>20$ \\
$\mathrm{Ca}$ & $<35$ & $35-45$ & $>50$ \\
$\mathrm{Mg}$ & $<2,5$ & $2,5-4,0$ & $>5,0$ \\
$\mathrm{~S}$ & $<2,0$ & $2,0-3,0$ & $>5,0$ \\
& & $-\mathbf{m g} / \mathbf{k g}$ & \\
$\mathrm{B}$ & $<36$ & $36-100$ & $>150$ \\
$\mathrm{Cu}$ & $<4,1$ & $4,1-10,0$ & $>15,0$ \\
$\mathrm{Fe}$ & $<50$ & $50-120$ & $>200$ \\
$\mathrm{Mn}$ & $<35$ & $35-50$ & $>100$ \\
$\mathrm{Zn}$ & $<35$ & $35-50$ & $>100$ \\
$\mathrm{Mo}$ & $<0,10$ & $0,10-1,00$ & $>2,00$ \\
\hline
\end{tabular}

(1) Para a variedade de laranja Westin, os teores adequados de Cu sugeridos são 10-20 $\mathrm{mg} / \mathrm{kg}$.

\subsection{1. Épocas de amostragens}

A primeira coleta de folhas foi feita no dia da pulverização, imediatamente antes do seu início. A segunda e a terceira amostragem foram realizadas aos 30 dias e 60 dias após a primeira.

\subsubsection{Sistema de amostragem}

Foram amostradas 5 plantas por parcela (ou seja as 5 plantas úteis). Coletouse a $3^{\mathrm{a}}$ ou $4^{\mathrm{a}}$ folha a partir do fruto, desde que não estivessem danificadas, em número de 4 folhas por planta, uma em cada quadrante e na altura mediana da copa. Assim, cada amostra foi composta de 20 folhas. 
As amostras foram acondicionadas em sacos de papel, etiquetadas e enviadas ao laboratório de análises do solo, do Departamento de Ciência do Solo da ESALQ/USP.

\subsubsection{Sistema de análise química das folhas}

As folhas foram lavadas em água mais detergente, passadas em água corrente, ácido clorídrico diluído e duas vezes com água deionizada e colocadas para secar em estufa a $70^{\circ} \mathrm{C}$, com circulação de ar forçada, até atingir peso constante.

As amostras foram moídas em moinho tipo Willey, pesadas e submetidas à digestão e quantificação segundo a metodologia descrita por Malavolta et al. (1989).

Para determinação de $\mathrm{N}$, o material vegetal moído submeteu-se à digestão sulfúrica e destilação em microdestilador Kjeldahl. Para o B a digestão foi pelo processo de incineração em meio alcalino e a determinação feita por colorimetria pela Azometina $\mathrm{H}$. Para os demais elementos a digestão realizada foi a nitro-perclórica, por via úmida.

$\mathrm{O} P$ foi determinado por colorimetria do metavanadato; o $\mathrm{K}$ pela fotometria de chama; o $\mathrm{S}$ por turbidimetria do sulfato de bário e os demais elementos $\mathrm{Ca}, \mathrm{Mg}, \mathrm{Cu}, \mathrm{Mn}$ e Zn por espectrofotometria de absorção atômica. 


\section{RESULTADOS E DISCUSSÃO}

\subsection{Teores foliares de nutrientes - Área 1.}

Os resultados da análise foliar para cobre, manganês, zinco e boro apresentados na tabela 12 expressam os teores encontrados no momento imediatamente anterior a pulverização foliar na área 1 .

Tabela 12. Teores foliares de $\mathrm{Cu}, \mathrm{Mn}, \mathrm{Zn}$ e B encontrados imediatamente antes da aplicacão na área 1.

\begin{tabular}{|c|c|c|c|c|c|c|}
\hline $\mathbf{N}^{\circ}$ & \multicolumn{2}{|c|}{ TRATAMENTOS } & $\mathrm{Cu}$ & Mn & $\mathbf{Z n}$ & B \\
\hline 1 & $\begin{array}{l}\text { Mancozeb } 80 \% \\
\text { Ácido bórico }\end{array}$ & $\begin{array}{l}4,0 \\
1,0\end{array}$ & 11 & 46 & 39 & $\overline{63}$ \\
\hline 2 & $\begin{array}{l}\text { Mancozeb } 80 \% \\
\text { Sulfato de zinco } \\
\text { Ácido bórico }\end{array}$ & $\begin{array}{l}4,0 \\
5,64 \\
1,0\end{array}$ & 12 & 52 & 46 & 61 \\
\hline 3 & $\begin{array}{l}\text { Mancozeb } 80 \% \\
\text { Sulfato de manganês } \\
\text { Ácido bórico }\end{array}$ & $\begin{array}{l}4,0 \\
1,63 \\
1,0\end{array}$ & 8 & 47 & 38 & 57 \\
\hline 4 & $\begin{array}{l}\text { Mancozeb } 80 \% \\
\text { Sulfato de zinco } \\
\text { Sulfato de manganês } \\
\text { Ácido bórico }\end{array}$ & $\begin{array}{l}4,0 \\
5,64 \\
1,63 \\
1,0 \\
\end{array}$ & 10 & 48 & 40 & 54 \\
\hline 5 & $\begin{array}{l}\text { Oxido cuproso } \\
\text { Ácido bórico }\end{array}$ & $\begin{array}{l}3,0 \\
1,0 \\
\end{array}$ & 14 & 55 & 44 & 57 \\
\hline 6 & $\begin{array}{l}\text { Oxido cuproso } \\
\text { Sulfato de zinco } \\
\text { Sulfato de manganês } \\
\text { Ácido bórico }\end{array}$ & $\begin{array}{l}3,0 \\
6,0 \\
4,0 \\
1,0\end{array}$ & $\overline{12}$ & 45 & 39 & 59 \\
\hline 7 & $\begin{array}{l}\text { Sulfato de zinco } \\
\text { Sulfato de manganês } \\
\text { Ácido bórico }\end{array}$ & $\begin{array}{l}6,0 \\
4,0 \\
1,0\end{array}$ & 8 & 50 & 43 & 55 \\
\hline 8 & Testemunha & - & 11 & 55 & 42 & 56 \\
\hline & $\begin{array}{l}\text { Teste F } \\
\text { DMS } \\
\text { CV }(\%)\end{array}$ & & $\begin{array}{c}1,31^{\text {ns }} \\
6,91 \\
30\end{array}$ & $\begin{array}{c}1,25^{\mathrm{ns}} \\
18,99 \\
15\end{array}$ & $\begin{array}{c}1,58^{\text {ns }} \\
9,97 \\
12\end{array}$ & $\begin{array}{c}0,74^{\text {11s }} \\
15,6 \\
13\end{array}$ \\
\hline
\end{tabular}


Os resultados das coletas feitas 30 e 60 dias após a aplicação encontra-se nas tabelas 13 e 14 respectivamente.

Tabela 13. Teores foliares de $\mathrm{Cu}, \mathrm{Mn}, \mathrm{Zn}$ e $\mathrm{B}$ encontrados 30 dias após a aplicação na área 1.

\begin{tabular}{|c|c|c|c|c|c|c|}
\hline $\mathrm{N}^{0}$ & \multicolumn{2}{|c|}{ TRATAMENTOS } & $\mathrm{Cu}$ & Mn & $\mathbf{Z n}$ & B \\
\hline 1 & $\begin{array}{l}\text { Mancozeb } 80 \% \\
\text { Ácido bórico }\end{array}$ & $\begin{array}{l}4,0 \\
1,0\end{array}$ & $4 b$ & $54 \mathrm{ab}$ & $24 c$ & 45 \\
\hline 2 & $\begin{array}{l}\text { Mancozeb } 80 \% \\
\text { Sulfato de zinco } \\
\text { Ácido bórico }\end{array}$ & $\begin{array}{l}4,0 \\
5,64 \\
1,0\end{array}$ & $4 b$ & $53 \mathrm{ab}$ & $40 \mathrm{abc}$ & 47 \\
\hline 3 & $\begin{array}{l}\text { Mancozeb } 80 \% \\
\text { Sulfato de manganês } \\
\text { Ácido bórico }\end{array}$ & $\begin{array}{l}4,0 \\
1,63 \\
1,0\end{array}$ & $4 \mathrm{~b}$ & $65 a$ & $24 c$ & 45 \\
\hline 4 & $\begin{array}{l}\text { Mancozeb } 80 \% \\
\text { Sulfato de zinco } \\
\text { Sulfato de manganês } \\
\text { Ácido bórico }\end{array}$ & $\begin{array}{l}4,0 \\
5,64 \\
1,63 \\
1,0 \\
\end{array}$ & $3 b$ & $63 a$ & $45 a$ & 46 \\
\hline 5 & $\begin{array}{l}\text { Óxido cuproso } \\
\text { Ácido bórico }\end{array}$ & $\begin{array}{l}3,0 \\
1,0 \\
\end{array}$ & $26 a$ & $38 b$ & $27 \mathrm{bc}$ & 50 \\
\hline 6 & $\begin{array}{l}\text { Oxido cuproso } \\
\text { Sulfato de zinco } \\
\text { Sulfato de manganês } \\
\text { Ácido bórico } \\
\end{array}$ & $\begin{array}{l}3,0 \\
6,0 \\
4,0 \\
1,0 \\
\end{array}$ & $19 a$ & $41 \mathrm{~b}$ & $31 \mathrm{abc}$ & 44 \\
\hline 7 & $\begin{array}{l}\text { Sulfato de zinco } \\
\text { Sulfato de manganês } \\
\text { Ácido bórico }\end{array}$ & $\begin{array}{l}6,0 \\
4,0 \\
1,0 \\
\end{array}$ & $5 b$ & $53 \mathrm{ab}$ & $44 a b$ & 47 \\
\hline 8 & Testemunha & - & $4 b$ & $38 b$ & $24 c$ & 43 \\
\hline & $\begin{array}{l}\text { Teste F } \\
\text { DMS } \\
\text { CV(\%) }\end{array}$ & & $\begin{array}{c}33,63^{*} \\
6,85 \\
38 \\
\end{array}$ & $\begin{array}{c}11,99^{*} \\
16,97 \\
13 \\
\end{array}$ & $\begin{array}{c}8,16^{* *} \\
14,75 \\
22 \\
\end{array}$ & $\begin{array}{c}0,83^{\mathrm{ns}} \\
10,51 \\
11 \\
\end{array}$ \\
\hline
\end{tabular}


Tabela 14. Teores foliares de $\mathrm{Cu}, \mathrm{Mn}, \mathrm{Zn}$ e $\mathrm{B}$ encontrados 60 dias após a aplicação na área 1.

\begin{tabular}{|c|c|c|c|c|c|c|}
\hline $\mathbf{N}^{0}$ & \multicolumn{2}{|c|}{ TRATAMENTOS } & $\mathrm{Cu}$ & Mn & $\mathbf{Z n}$ & B \\
\hline 1 & $\begin{array}{l}\text { Mancozeb } 80 \% \\
\text { Ácido bórico }\end{array}$ & $\begin{array}{l}4,0 \\
1,0\end{array}$ & $3 b$ & $65 \mathrm{ab}$ & $17 \mathrm{a}$ & 83 \\
\hline 2 & $\begin{array}{l}\text { Mancozeb } 80 \% \\
\text { Sulfato de zinco } \\
\text { Ácido bórico }\end{array}$ & $\begin{array}{l}4,0 \\
5,64 \\
1,0\end{array}$ & $4 b$ & $62 \mathrm{abc}$ & $29 a$ & 79 \\
\hline 3 & $\begin{array}{l}\text { Mancozeb } 80 \% \\
\text { Sulfato de manganès } \\
\text { Ácido bórico }\end{array}$ & $\begin{array}{l}4,0 \\
1,63 \\
1,0\end{array}$ & $4 b$ & 74ab & $13 \mathrm{bc}$ & 73 \\
\hline 4 & $\begin{array}{l}\text { Mancozeb } 80 \% \\
\text { Sulfato de zinco } \\
\text { Sulfato de manganês } \\
\text { Ácido bórico }\end{array}$ & $\begin{array}{l}4,0 \\
5,64 \\
1,63 \\
1,0 \\
\end{array}$ & $3 b$ & $76 a$ & $32 a$ & 71 \\
\hline 5 & $\begin{array}{l}\text { Óxido cuproso } \\
\text { Ácido bórico }\end{array}$ & $\begin{array}{l}3,0 \\
1,0\end{array}$ & $18 \mathrm{a}$ & $38 \mathrm{a}$ & $10 \mathrm{bc}$ & 77 \\
\hline 6 & $\begin{array}{l}\text { Oxido cuproso } \\
\text { Sulfato de zinco } \\
\text { Sulfato de manganês } \\
\text { Ácido bórico }\end{array}$ & $\begin{array}{l}3,0 \\
6,0 \\
4,0 \\
1,0\end{array}$ & $\overline{16 a}$ & $46 \mathrm{cde}$ & $17 a$ & 75 \\
\hline 7 & $\begin{array}{l}\text { Sulfato de zinco } \\
\text { Sulfato de manganês } \\
\text { Ácido bórico }\end{array}$ & $\begin{array}{l}6,0 \\
4,0 \\
1,0 \\
\end{array}$ & $4 b$ & $58 \mathrm{bcd}$ & $27 \mathrm{ac}$ & 73 \\
\hline 8 & Testemunha & - & $3 \mathrm{~b}$ & $42 \mathrm{~d}$ & $7 \mathrm{c}$ & 69 \\
\hline & $\begin{array}{l}\text { Teste F } \\
\text { DMS } \\
\text { CV }(\%)\end{array}$ & & $\begin{array}{c}191,09^{* *} \\
2,14 \\
15 \\
\end{array}$ & $\begin{array}{c}21,16^{* *} \\
17,45 \\
12 \\
\end{array}$ & $\begin{array}{c}48,09^{* *} \\
6,19 \\
16 \\
\end{array}$ & $\begin{array}{c}0,77^{\text {ns }} \\
17,54 \\
13 \\
\end{array}$ \\
\hline
\end{tabular}

\subsubsection{Cobre}

Os teores de cobre encontrados nas folhas anteriormente as aplicações dos tratamentos, não diferiram significativamente entre si, cujo valor médio foi de $10 \mathrm{mg} / \mathrm{kg}$ (Tabela 12), considerado adequado segundo GPACC (1994).

Aos 30 dias após a aplicação (Tabela 13) os tratamentos que receberam fungicida cúprico (óxido cuproso) apresentaram-se com teores elevados de cobre chegando ao nível excessivo (Figura 1), e aos 60 dias (Tabela 12) observou-se pequena redução porém ainda mantendo valores altos e bem superiores aos demais tratamentos, 
concordando com os resultados observados por diversos autores (Malavolta et al., 1989 ; Alva et al., 1993 e Rodriguez, 1991).

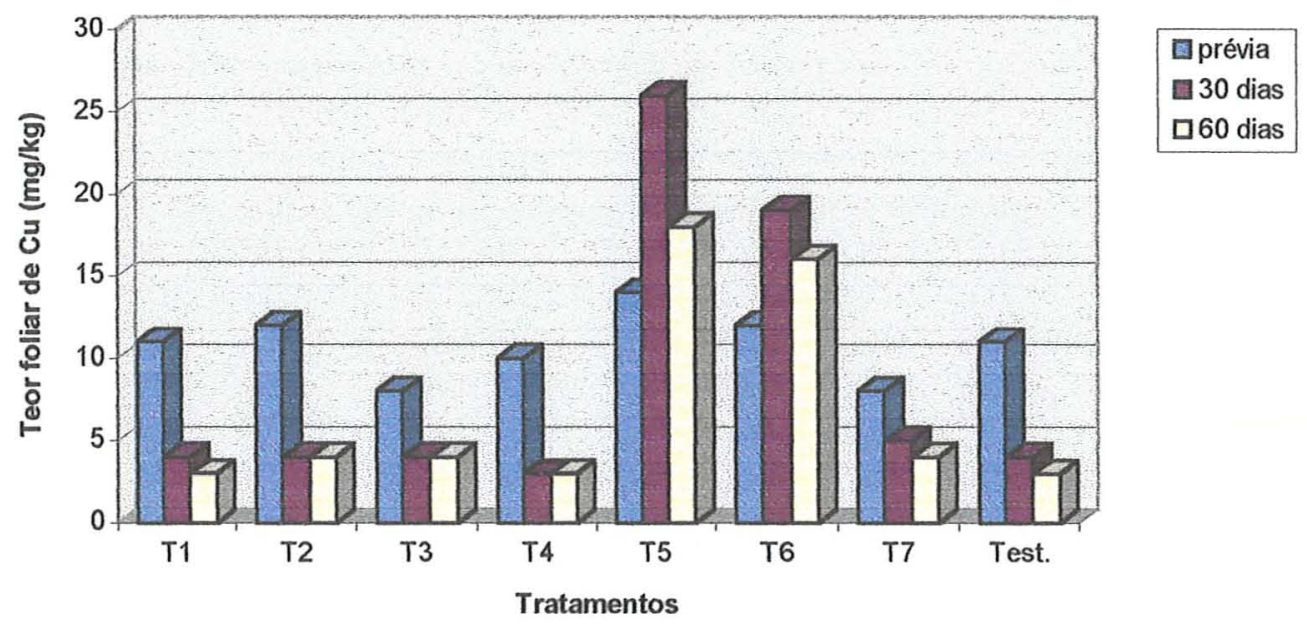

Figura 1. Teores foliares de cobre encontrados em três épocas de amostragem (prévia, 30 e 60 dias após a aplicação) nos tratamentos da área 1 .

Nos demais tratamentos constatou-se uma redução visível nos teores foliares de cobre, nas duas épocas amostradas sendo todos considerados baixos (Figura 1). Este fato pode estar relacionado com o efeito de diluíção, gerado por um aumento no estadio vegetativo, ocasionado pelo aumento do fornecimentode nitrogênio tanto pela adubação realizada como também pela mineralização da matéria orgânica, resultados estes confirmados por Malavolta (1976); Olsen (1972).

\subsubsection{Manganês}

Os teores de manganês apresentados na amostragem prévia realizada indicam que a área estava bastante homogênea e com teores adequados para este micronutriente (Tabela 12).

Passados 30 e 60 dias nota-se que ocorreram variações nos teores de manganês nos vários tratamentos (Tabela 13).

Todas as plantas tratadas com mancozeb apresentavam teores elevados de manganês. Os maiores teores foram verificados nos tratamentos que receberam também 
complementação com sulfato de manganês, enquanto que aqueles que receberam mancozeb sem suplementação apresentaram -se com teores adequados e apenas ligeiramente inferiores, indicando ser desnecessário acrescentar outra fonte complementar deste nutriente pois foram valores similares aqueles do tratamento com sais (Tratamento 7) na ausência de fungicida cúprico (Figura 2).

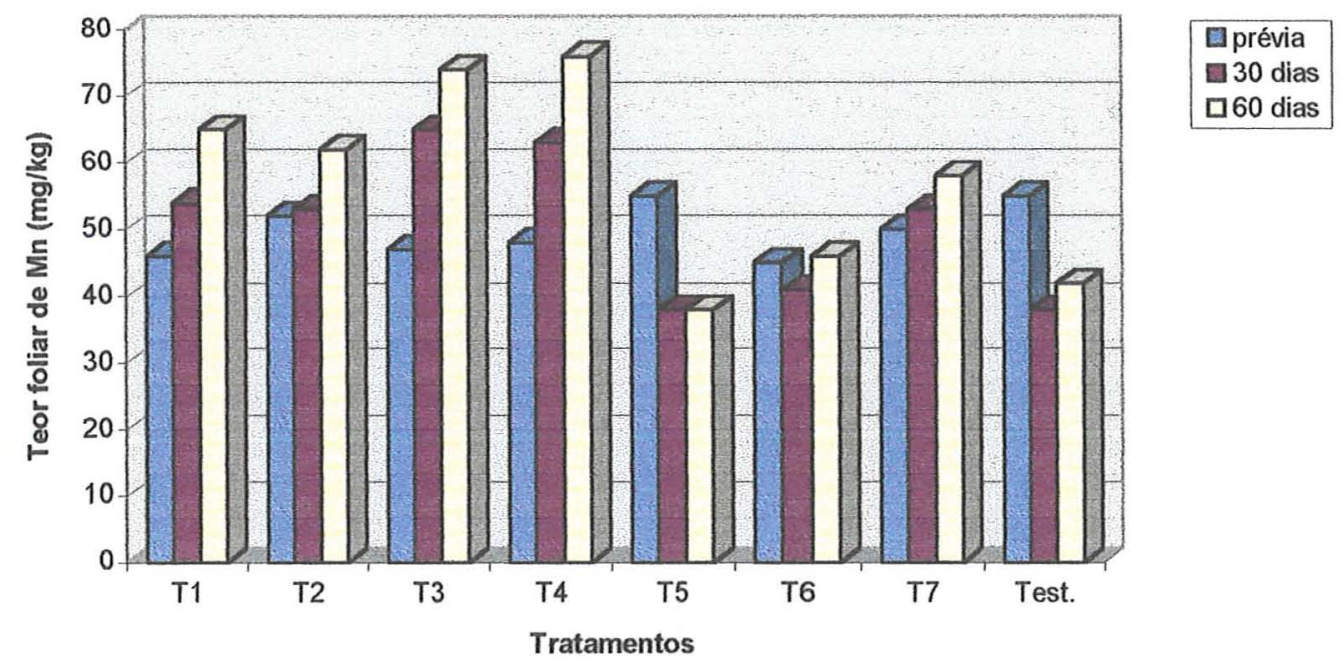

Figura 2. Teores foliares de manganês encontrados em três épocas de amostragem (prévia, 30 e 60 dias após a aplicação ) nos tratamentos da área 1 .

Os menores teores foliares de manganês, entre as plantas dos tratamentos que receberam aplicação de alguma fonte deste elemento, foram observados quando utilizou-se a mistura de sais com óxido cuproso (Tratamento 6) chegando a ser estatisticamente semelhante aos 30 e 60 dias com os teores foliares das plantas dos tratamentos que não receberam manganês (Tratamentos 5 e 8).

A quantidade de manganês fornecida pelos tratamentos com sulfato de manganês a 4,0 kg/2000L foi de $1008 \mathrm{~g}$ de $\mathrm{Mn}$ enquanto que do mancozeb (80\% de concentração de Mn) a 4,0 kg /2000L foi de $520 \mathrm{~g}$ de Mn (Tabelas 7 e 8). Considerando que os teores foliares das plantas tratadas com mancozeb foram semelhantes àqueles com sulfato de manganês mesmo tendo o primeiro fornecido pouco mais da metade da quantidade deste nutriente, pode-se inferir então numa eficiência maior no suprimento via mancozeb. Esta eficiência pode ser explicada pela composição química do mancozeb , uma 
vez que o elemento $\mathrm{Mn}$ aparece ligado a uma molécula orgânica (Figura 3) o que eventualmente pode levar a um comportamento parecido ao dos quelados no processo de absorção foliar.

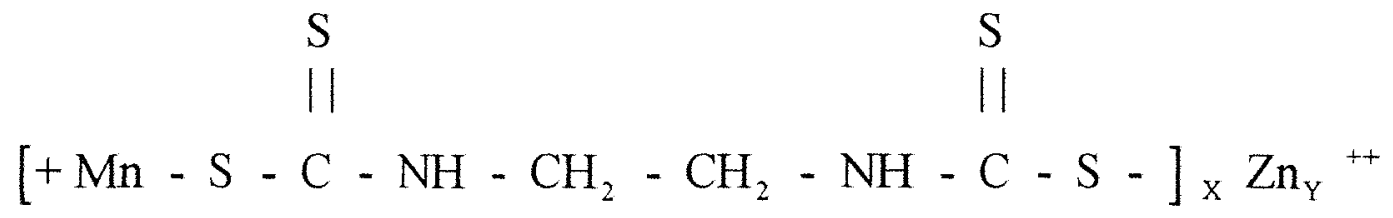

Figura 3. Fórmula estrutural do mancozeb (produto de coordenação iônica de etilenobisditiocarbamato de manganês com íon zinco).

\subsubsection{Zinco}

Antes das aplicações, os teores foliares de zinco encontravam-se estatisticamente semelhantes e dentro da faixa considerada adequada pelo GPACC (1994), conforme pode ser o observado na tabela 12 .

Aos 30 dias da aplicação dos tratamentos, entretanto, observou-se teores superiores nas plantas tratadas com sulfato de zinco, com ou sem mancozeb. A exceção foi a mistura de sulfato de zinco com óxido cuproso (Tratamento 6) que apresentou valores baixos e próximos aos tratamentos sem sulfato de zinco (Tabela 13).

Estes teores mais baixos de zinco já a partir de 30 dias mostraram o efeito competitivo que ocorreu entre os cátions de cobre e zinco no momento da aplicação foliar, concordando com os trabalhos de Steyn e Eve (1956), Mam \& Takkan (1983) e Vitti (1992).

Os tratamentos com mancozeb sem suplementação de sulfato de zinco não foram capazes de manter os teores foliares de zinco aos 30 dias, o que era de se esperar pois o teor de zinco no produto é muito baixo, os quais não diferiram da testemunha e do tratamento sem nenhuma fonte de zinco.Isto mostra que o mancozeb não forneceu o zinco suficiente para atender as necessidades da planta. 
Com estes resultados ficou claro também a grande demanda por zinco que a planta cítrica apresentou após o inicio da vegetação de florada uma vez que depois de apenas 30 dias os teores foliares passaram rapidamente da faixa adequada para a deficiente (Tratamentos 1,3,5,6 e 8), mesmo considerando ser o zinco um elemento com mobilidade reduzida na planta.

Aos 60 dias este fato pode ser observado de maneira mais evidente, onde os tratamentos apresentaram-se com teores menores que os considerados adequados, indicando claramente a necessidade de novo fornecimento de zinco nesta época.

A figura 4 mostra a queda nos teores foliares de zinco, em função dos períodos de amostragem, baseado no tratamento sem fornecimento de zinco (testemunha).

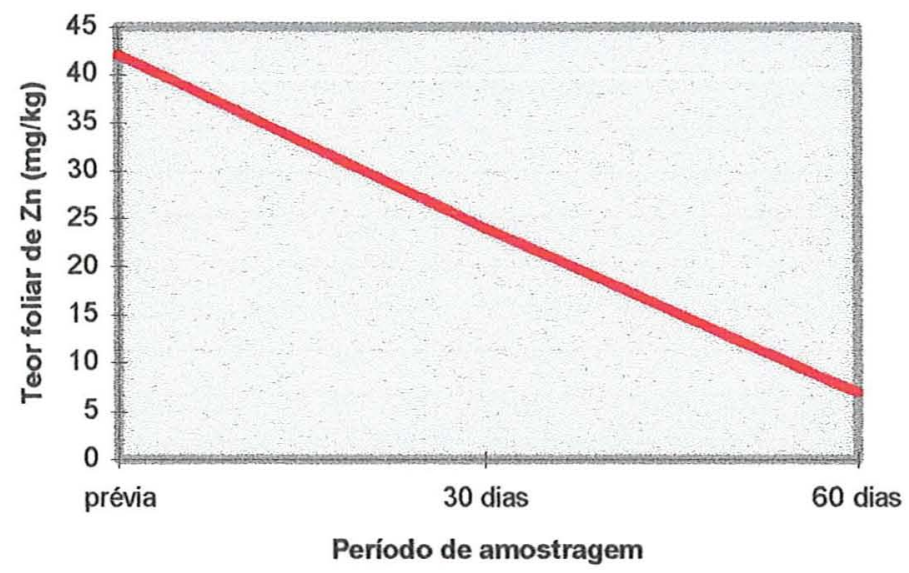

Figura 4.Teores foliares de zinco encontrados nos períodos de amostragem (prévia, 30 e 60 dias após a aplicação) na testemunha da área 1.

Os teores foliares de zinco mais altos aos 60 dias foram encontrados nas plantas dos tratamentos com fornecimento de sulfato de zinco sem óxido cuproso (Tratamento 2, 4, e 7).

As plantas que não receberam fonte de zinco (Tratamentos 5 e 8 ) apresentaram os mais baixos níveis foliares do elemento aos 60 dias, como era de se esperar.

O nível foliar após 60 dias da aplicação de mancozeb sem acréscimo de sulfato de zinco (Tratamentos 1 e 3), embora tenha sido bastante baixo, foi ainda 
ligeiramente superior a testemunha podendo indicar um pequeno efeito do zinco contido no mancozeb.

Confirmando a tendência encontrada aos 30 dias os teores foliares de zinco aos 60 dias, das plantas que receberam sulfato de zinco associado com óxido cuproso (Tratamento 6), foram muito baixos aproximando-se dos tratamentos que não receberam sulfato de zinco, indicando a competição entre cobre e zinco ocorrido no período da aplicação, caracterizando-se pela inibição na absorção de zinco conforme observado por Steyn \& Eve (1956).

A figura 5 apresenta os níveis foliares de zinco nas três épocas de amostragem.

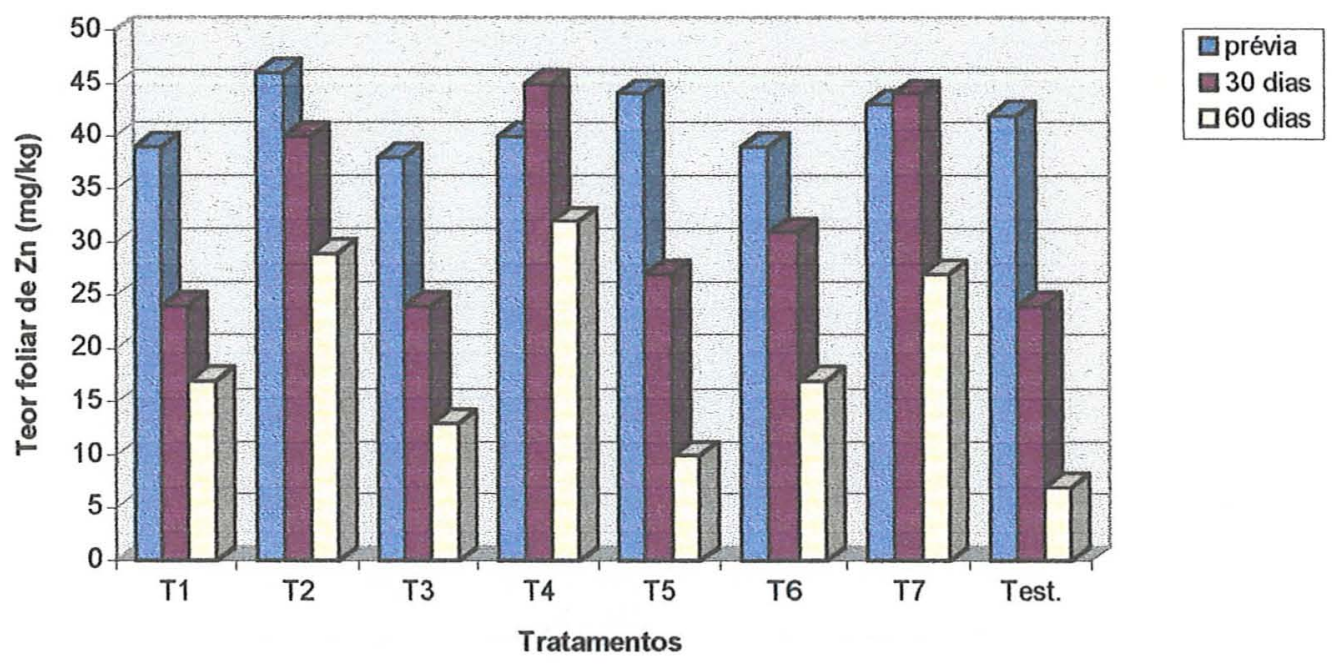

Figura 5. Teores foliares de zinco encontrados em três épocas de amostragem (prévia, $30 \mathrm{e}$ 60 dias após a aplicação ) nos tratamentos da área 1.

\subsubsection{Boro}

Não houve diferença significativa entre os tratamentos para teor foliar de boro. (tabelas 12, 13 e 14). Isto pode ser explicado pelo fornecimento de boro ter sido feito anteriormente pela adubação via solo na forma de óxidos silicatados, modo este altamente eficinte no fornecimento de boro, conforme observado por Cabrita (1994).

Após 60 dias da florada notou-se um aumento no teor foliar em todos os tratamentos (figura 6). 


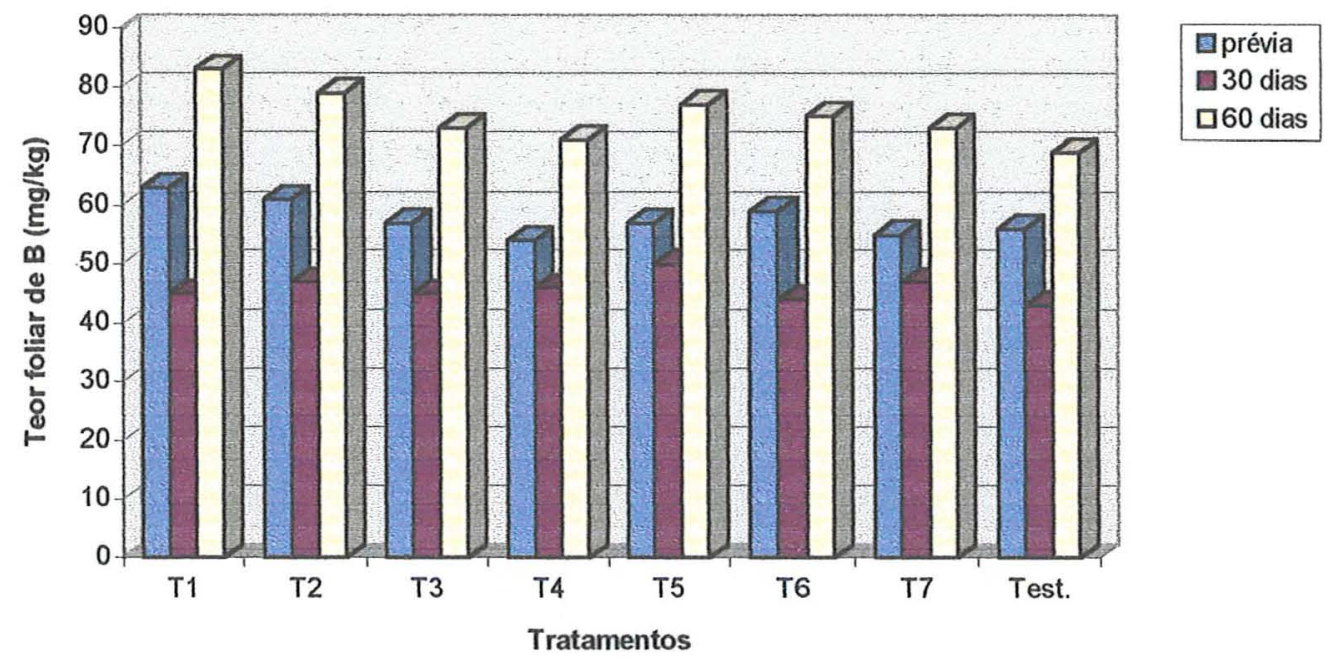

Figura 6. Teores foliares de boro encontrados em três épocas de amostragem (prévia, $30 \mathrm{e}$ 60 dias após a aplicação) nos tratamentos da área 1.

Este aumento pode ser explicado em parte pela maior precipitação ocorrida no período de condução do ensaio (Tabela 1) que favoreceu a mineralização da matéria orgânica do solo, além do boro colocado via adubação que sofreu maior possibilidade de solubilização da fonte utilizada.

A baixa mobilidade de boro via floema deve ter também contribuído para a ausência de diferenças significativas entre os tratamentos que forneceram boro via foliar e a testemunha sem boro.

\subsection{Teores foliares de nutrientes - Área 2}

\subsubsection{Macronutrientes}

Os resultados da análise foliar para nitrogênio, fósforo, potássio, cálcio, magnésio e enxofre encontram-se nas Tabelas 15, 16 e 17 imediantamente antes da aplicação, 30 e 60 dias após, respectivamente. 
Tabela 15. Teores foliares de N, P, K, Ca, Mg e S encontrados imediatamente antes da aplicação na área 2.

\begin{tabular}{|c|c|c|c|c|c|c|c|}
\hline $\mathrm{N}^{0}$ & TRATAMENTOS & $\mathbf{N}$ & $\mathbf{P}$ & $\mathbf{K}$ & $\mathbf{C a}$ & $\mathrm{Mg}$ & $\mathbf{S}$ \\
\hline 1 & $\begin{array}{l}\text { Oxicloreto de cobre } \\
\text { M.S. }\end{array}$ & 24 & 1,0 & 10 & 53 & 1,6 & 1,2 \\
\hline 2 & $\begin{array}{l}\text { Hidróxido de cobre } \\
\text { M.S. }\end{array}$ & 20 & 1,0 & 8,8 & 45 & 2,0 & 1,2 \\
\hline 3 & $\begin{array}{l}\text { Oxido cuproso } \\
\text { M.S. }\end{array}$ & 26 & 1,1 & 11 & 57 & 1,4 & 1,2 \\
\hline 4 & $\begin{array}{l}\text { Benomyl } \\
\text { M.S. }\end{array}$ & 25 & 1,0 & 10 & 54 & 1,8 & 1,4 \\
\hline 5 & $\begin{array}{l}\text { Oxicloreto de cobre } \\
\text { M.Q. }\end{array}$ & 25 & 1,0 & 11 & 52 & 1,8 & 1,3 \\
\hline 6 & $\begin{array}{l}\text { Hidróxido de cobre } \\
\text { M.Q. }\end{array}$ & 23 & 1,0 & 11 & 54 & 2,0 & 1,4 \\
\hline 7 & $\begin{array}{l}\text { Óxido cuproso } \\
\text { M.Q. }\end{array}$ & 24 & 0,9 & 11 & 52 & 2,0 & 1,0 \\
\hline 8 & $\begin{array}{l}\text { Benomyl } \\
\text { M.Q. }\end{array}$ & 24 & 1,0 & 11 & 57 & 1,4 & 1,3 \\
\hline 9 & Testemunha & 24 & 0,9 & 11 & 55 & 2,0 & 1,3 \\
\hline & Teste F & $0,89^{\mathrm{ns}}$ & $0,88^{\text {ns }}$ & $1,32^{\mathrm{ns}}$ & $0,93^{\mathrm{ns}}$ & $2,72^{\text {ns }}$ & $0,76^{\mathrm{ns}}$ \\
\hline & DMS & 0,81 & 0,03 & 0,35 & 1,69 & 0,79 & 0,07 \\
\hline & $\mathrm{CV}(\%)$ & 16 & 13 & 15 & 15 & 21 & 25 \\
\hline
\end{tabular}

Legenda: Doses para 2000 litros de solução.

M.S. = Mistura de Sais: Sulfato de zinco 6,0kg; Sulfato de manganês $4,0 \mathrm{~kg}$; Ácido bórico $1,0 \mathrm{~kg}$ e Uréia $10,0 \mathrm{~kg}$.

M.Q.= Mistura de Quelados: Ager zinco 0,8 L; Ager manganês 0,8 L; Ager boro 1,0 L e Uréia $10,0 \mathrm{~kg}$. 
Tabela 16. Teores foliares de $\mathrm{N}, \mathrm{P}, \mathrm{K}, \mathrm{Ca}, \mathrm{Mg}$ e $\mathrm{S}$ encontrados aos 30 dias após a aplicação na área 2.

\begin{tabular}{|c|c|c|c|c|c|c|c|}
\hline $\mathrm{N}^{0}$ & TRATAMENTOS & $\mathbf{N}$ & $\mathbf{P}$ & $\mathbf{K}$ & Ca & Mg & $\mathbf{S}$ \\
\hline 1 & $\begin{array}{l}\text { Oxicloreto de cobre } \\
\text { M.S. }\end{array}$ & 25 & 1,2 & $12 b$ & 45 & 2,3 & 1,8 \\
\hline 2 & $\begin{array}{l}\text { Hidróxido de cobre } \\
\text { M.S. }\end{array}$ & 26 & 1,3 & $13 a b$ & 45 & 2,6 & 2,0 \\
\hline 3 & $\begin{array}{l}\text { Oxido cuproso } \\
\text { M.S. }\end{array}$ & 25 & 1,3 & $14 a$ & 48 & 2,2 & 1,8 \\
\hline 4 & $\begin{array}{l}\text { Benomyl } \\
\text { M.S. }\end{array}$ & 25 & 1,1 & $12 \mathrm{~b}$ & 50 & 2,3 & 1,9 \\
\hline 5 & $\begin{array}{l}\text { Oxicloreto de cobre } \\
\text { M.Q. }\end{array}$ & 25 & 1,3 & $12 b$ & 45 & 2,3 & 1,8 \\
\hline 6 & $\begin{array}{l}\text { Hidróxido de cobre } \\
\text { M.Q. }\end{array}$ & 27 & 1,1 & $13 a b$ & 45 & 2,5 & 1,7 \\
\hline 7 & $\begin{array}{l}\text { Oxido cuproso } \\
\text { M.Q. }\end{array}$ & 25 & 1,2 & $12 b$ & 49 & 2,4 & 1,8 \\
\hline 8 & $\begin{array}{l}\text { Benomyl } \\
\text { M.Q. }\end{array}$ & 25 & 1,2 & $12 b$ & 47 & 2,4 & 2,0 \\
\hline 9 & Testemunha & 25 & 1,2 & $12 \mathrm{~b}$ & 47 & 2,3 & 1,7 \\
\hline & Teste F & $0,66^{\mathrm{ns}}$ & $0,91^{\mathrm{nS}}$ & $1,99^{* * *}$ & $1,18^{\mathrm{ns}}$ & $0,98^{\text {ns }}$ & $1,76^{\mathrm{ng}}$ \\
\hline & DMS & 0,38 & 0,04 & 0,19 & 0,85 & 0,05 & 0,03 \\
\hline & $\mathrm{CV}(\%)$ & 7 & 15 & 9 & 9 & 10 & 8 \\
\hline
\end{tabular}

Legenda: Doses para 2000 litros de solução.

M.S. = Mistura de Sais: Sulfato de zinco 6,0kg; Sulfato de manganês 4,0 kg; Ácido bórico $1,0 \mathrm{~kg}$ e Uréia $10,0 \mathrm{~kg}$.

M.Q.= Mistura de Quelados: Ager zinco 0,8 L; Ager manganês 0,8 L; Ager boro 1,0 L e Uréia $10,0 \mathrm{~kg}$. 
Tabela 17. Teores foliares de $\mathrm{N}, \mathrm{P}, \mathrm{K}, \mathrm{Ca}, \mathrm{Mg}$ e $\mathrm{S}$ encontrados aos 60 dias após a aplicação na área 2.

\begin{tabular}{|c|c|c|c|c|c|c|c|}
\hline $\mathbf{N}^{\mathbf{0}}$ & TRATAMENTO & $\mathbf{N}$ & $\mathbf{P}$ & $\mathbf{K}$ & $\mathrm{Ca}$ & Mg & $\mathrm{S}$ \\
\hline 1 & $\begin{array}{l}\text { Oxicloreto de cobre } \\
\text { M.S. }\end{array}$ & 29 & 1,8 & 18 & 27 & 2,8 & 2,8 \\
\hline 2 & $\begin{array}{l}\text { Hidróxido de cobre } \\
\text { M.S. }\end{array}$ & 29 & 1,8 & 17 & 26 & 2,7 & 2,8 \\
\hline 3 & $\begin{array}{l}\text { Óxido cuproso } \\
\text { M.S. }\end{array}$ & 29 & 1,9 & 20 & 26 & 2,6 & 2,9 \\
\hline 4 & $\begin{array}{l}\text { Benomyl } \\
\text { M.S. }\end{array}$ & 30 & 1,8 & 15 & 25 & 3,0 & 3,0 \\
\hline 5 & $\begin{array}{l}\text { Oxicloreto de cobre } \\
\text { M.Q. }\end{array}$ & 29 & 1,8 & 18 & 25 & 3,0 & 2,8 \\
\hline 6 & $\begin{array}{l}\text { Hidróxido de cobre } \\
\text { M.Q. }\end{array}$ & 29 & 1,8 & 18 & 25 & 3,0 & 2,8 \\
\hline 7 & $\begin{array}{l}\text { Óxido cuproso } \\
\text { M.Q. }\end{array}$ & 29 & 1,8 & 17 & 26 & 3,1 & 2,8 \\
\hline 8 & $\begin{array}{l}\text { Benomyl } \\
\text { M.Q. }\end{array}$ & 29 & 1,7 & 18 & 26 & 2,9 & 2,8 \\
\hline 9 & Testemunha & 30 & 1,8 & 18 & 27 & 3,1 & 2,9 \\
\hline & Teste $\mathrm{F}$ & $0,42^{\mathrm{ns}}$ & $0,84^{\mathrm{ns}}$ & $1,47^{\text {ns }}$ & $1,58^{\text {ns }}$ & $2,16^{\mathrm{ns}}$ & $0,28^{\mathrm{ns}}$ \\
\hline & DMS & 0,29 & 0,03 & 0,48 & 2,55 & 0,05 & 0,05 \\
\hline & $\mathrm{CV}(\%)$ & 5 & 8 & 4 & 5 & 7 & 8 \\
\hline
\end{tabular}

Legenda: Doses para 2000 litros de solução.

M.S. = Mistura de Sais: Sulfato de zinco 6,0kg; Sulfato de manganês $4,0 \mathrm{~kg}$; Ácido bórico $1,0 \mathrm{~kg}$ e Uréia $10,0 \mathrm{~kg}$.

M.Q.= Mistura de Quelados: Ager zinco 0,8 L; Ager manganês 0,8 L; Ager boro 1,0 L e Uréia $10,0 \mathrm{~kg}$.

\subsubsection{Nitrogênio}

Não houve diferença entre os tratamentos para os teores foliares de nitrogênio em todas as épocas amostradas, como pode-se observar nas tabelas 15,16 e 17, indicando não ter sido encontrado nenhum efeito da uréia no aumento do teor foliar do nitrogênio nas doses aplicadas.

No entanto, encontrou-se tendência de variaçào nos niveis foliares quando comparou-se a média dos tratamentos nos três periodos amostrados (Figura 7). 


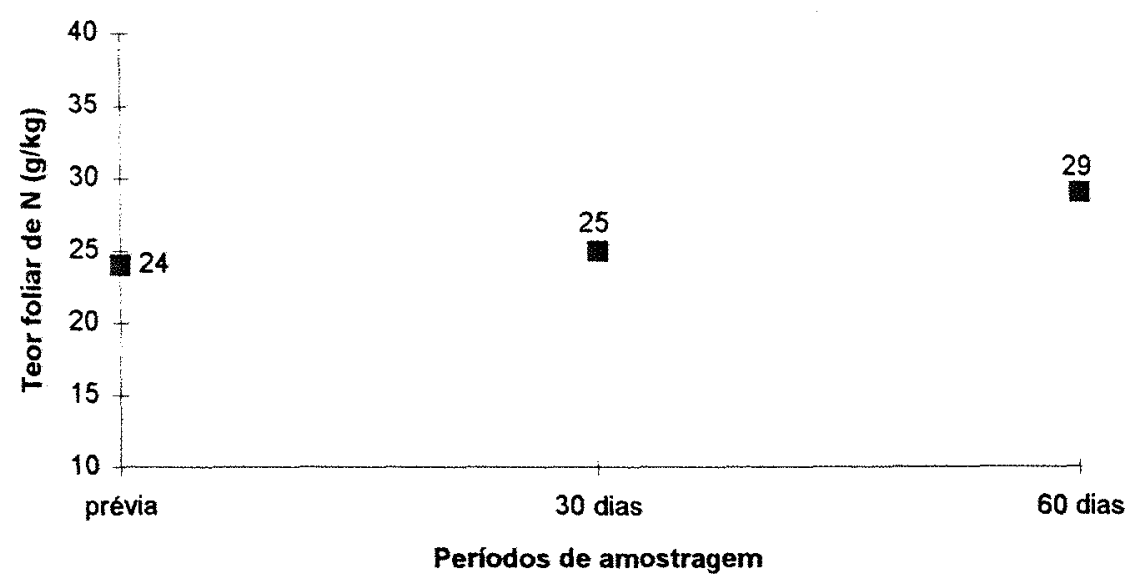

Figura 7. Média dos teores foliares de nitrogênio encontrados nos períodos de amostragem, (prévia, 30 e 60 dias após a aplicação) na área 2.

Esta diferença pode ser explicada inicialmente pelo aumento da precipitação pluviométrica e consequentemente pelo aumento da mineralização da matéria orgânica e também pela própria adubação nitrogenada realizada no período da florada através da aplicação de $500 \mathrm{~g}$ da fórmula 12-06-12 (Tabela 10 ), que forneceu $180 \mathrm{~g}$ de $\mathrm{N}$ por planta, que contribuiu para este aumento do nitrogênio foliar.

\subsubsection{Fósforo}

$O$ teor de fósforo foliar não apresentou variação significativa entre os tratamentos nos três períodos amostrados, conforme pode ser observado nas tabelas 15,16 e 17 .

Em relação aos teores foliares médios entre os períodos de amostragem, notamos uma grande variação nos níveis de fósforo (Figura 8). 


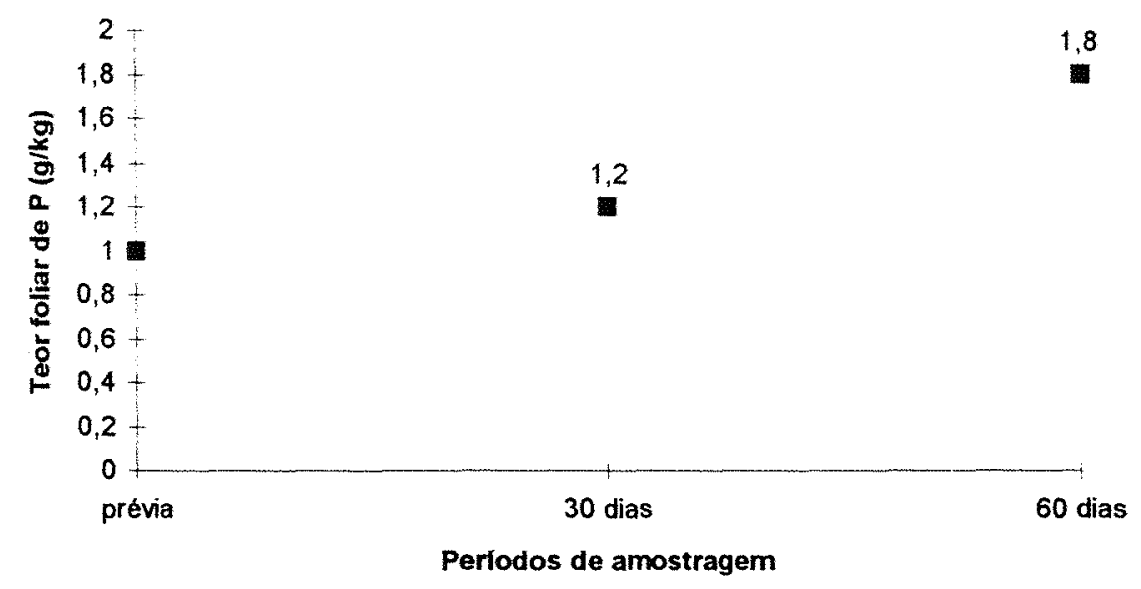

Figura 8. Média dos teores foliares de fósforo encontrados nos períodos de amostragem, (prévia, 30 e 60 dias após a aplicação) na área 2.

Como pode-se observar houve aumento foliar nos niveis de fósforo chegando a ficar quase $80 \%$ superior ao início.

Considerando a alta mobilidade do fósforo no interior da planta e que foram analisadas somente folhas maduras refere-se que suprimento de fósforo via solo foi suficiente para elevar os niveis da faixa de baixo para adequado.

Este suprimento deve-se praticamente a própria adubação via solo que forneceu $90 \mathrm{~g}$ de $\mathrm{P}_{2} \mathrm{O}_{5}$ por planta.

\subsubsection{Potássio}

Em relação ao potássio, não foi encontrado nenhuma correlação entre teor foliar do elemento e os tratamentos empregados, uma vez que os teores não diferiram entre si dentro de cada período da amostragem (Tabelas 15, 16 e 17).

Assim, como aconteceu com o nitrogênio e o fósforo os níveis foliares de potássio médios aumentaram após 60 dias da florada (Figura 9). 


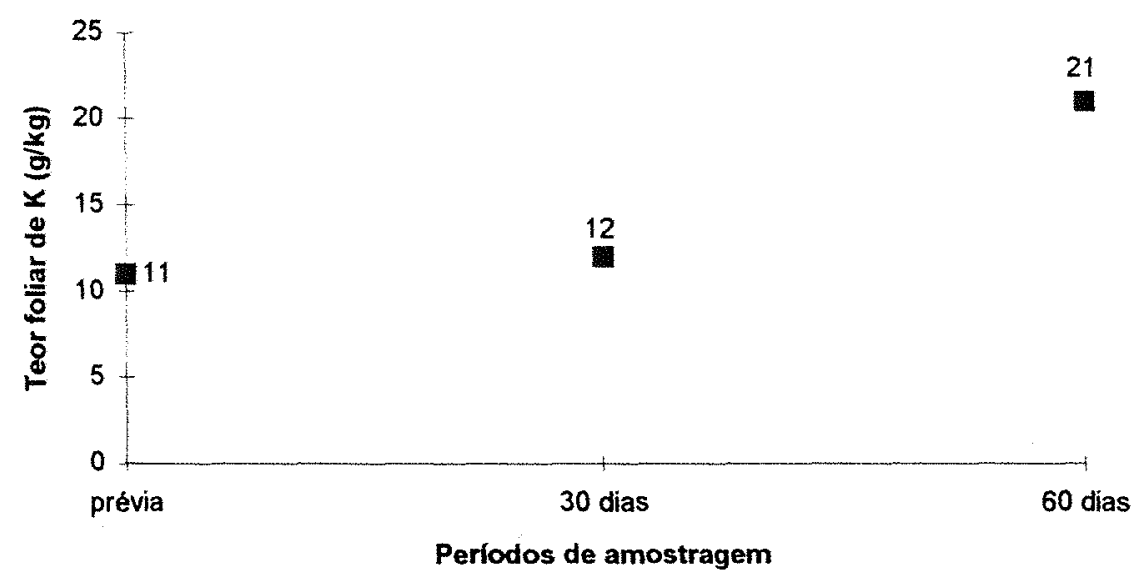

Figura 9. Média dos teores foliares de potássio encontrados nos períodos de amostragem, (prévia, 30 e 60 dias após a aplicação) na área 2.

A figura 9 mostra o aumento do teor foliar de potássio aos 60 dias, chegando a níveis considerados excessivos, o que pode ser explicado pelo fornecimento de $180 \mathrm{~g}$ de $\mathrm{K}_{2} \mathrm{O}$ via adubação no solo no período da florada.

\subsubsection{Cálcio e Magnésio}

Através da tabelas 15,16 e 17 observa-se que não houve variação entre os tratamentos para teores foliares de cálcio e magnésio nas três épocas de amostragem.

Pode-se contudo, observar diferenças nos teores destes elementos quando compara-se as épocas de amostragem (Figuras 10 e 11). 


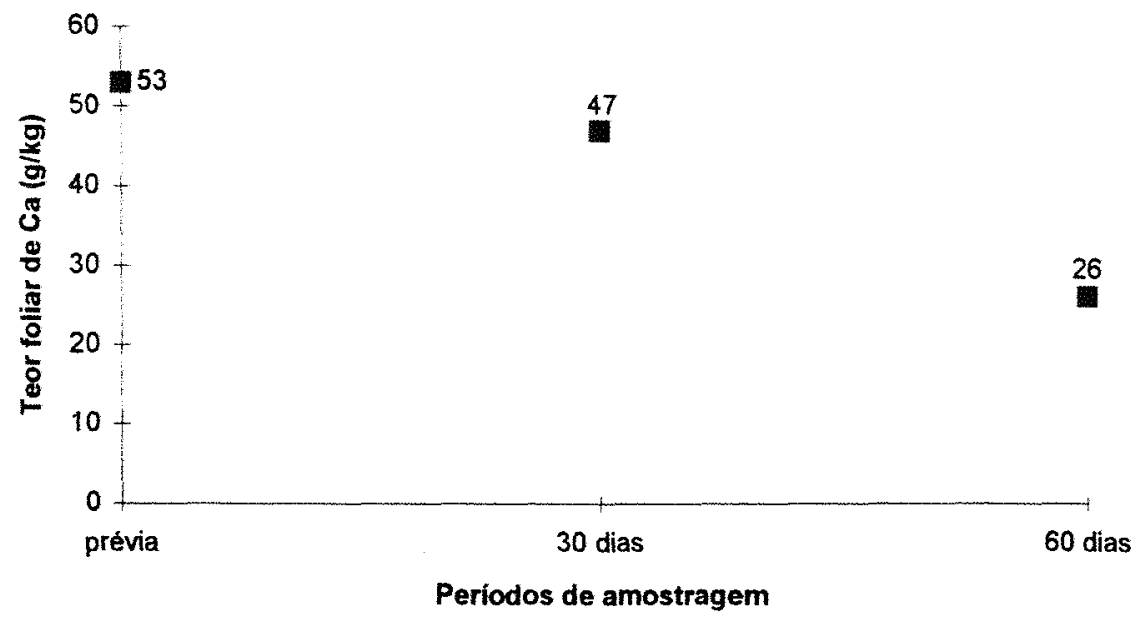

Figura 10. Média dos teores foliares de cálcio encontrados nos períodos de amostragem, (prévia, 30 e 60 dias após a aplicação) na área 2.

Observa-se queda acentuada nos teores de cálcio foliar (figura 10) passando de teor excessivo a teores considerados baixos após 60 dias (praticamente a metade do inicia, figura 11).

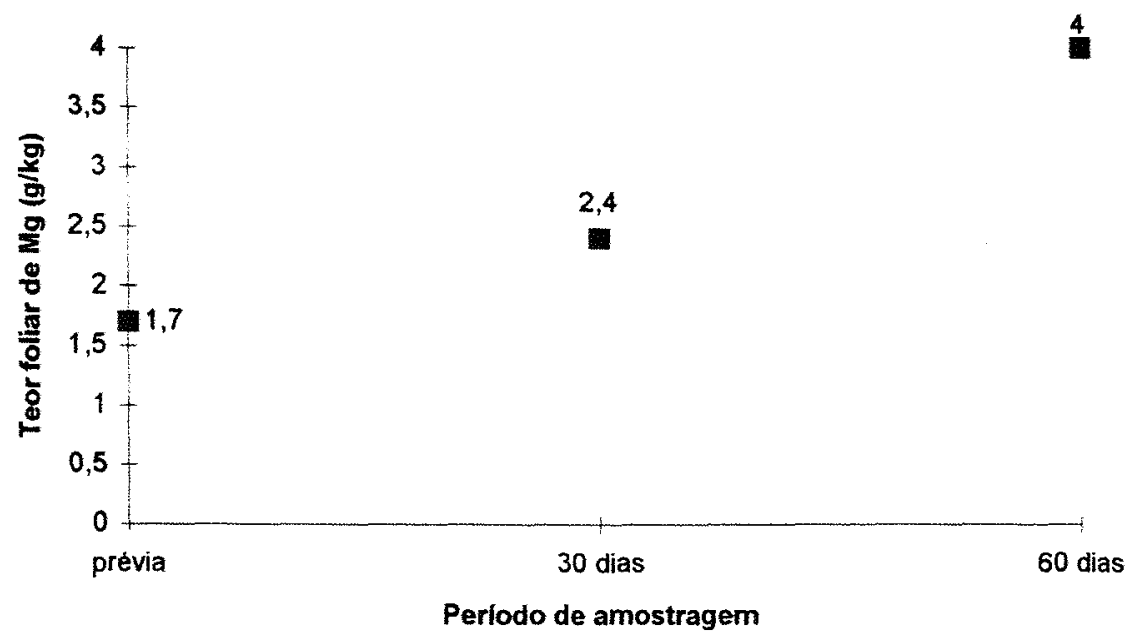

Figura 11. Média dos teores foliares de magnésio encontrados nos períodos de amostragem, (prévia, 30 e 60 dias após a aplicação) na área 2. 
Em relação ao magnésio a situação é a inversa uma vez que os teores partem de patamares considerados baixos chegando a níveis adequados (aproximadamente o dobro dos iniciais).

Como pode-se observar anteriormente, os teores de potássio foliar também aumentaram com o tempo na mesma proporção do que o magnésio e inversamente ao cálcio. Houve praticamente uma redução de $50 \%$ nos teores foliar de cálcio acompanhado de uma duplicação nos teores foliares de magnésio e potássio, sugerindo um certo equilibrio entre estes elementos no inteiror da folha.

\subsubsection{Enxofre}

Assim como os demais macronutrientes, não foram constatadas variações nos níveis de enxofre foliar entre os tratamentos conforme observa-se nas tabelas $15,16 \mathrm{e}$ 17. O fornecimento de zinco e manganês na forma de sulfato não causou interferência nos níveis foliares de enxofre. Em relação as épocas de amostragem, encontrou-se aumento nos teores médios foliares de enxofre após 30 e 60 dias da florada (Figura 12).

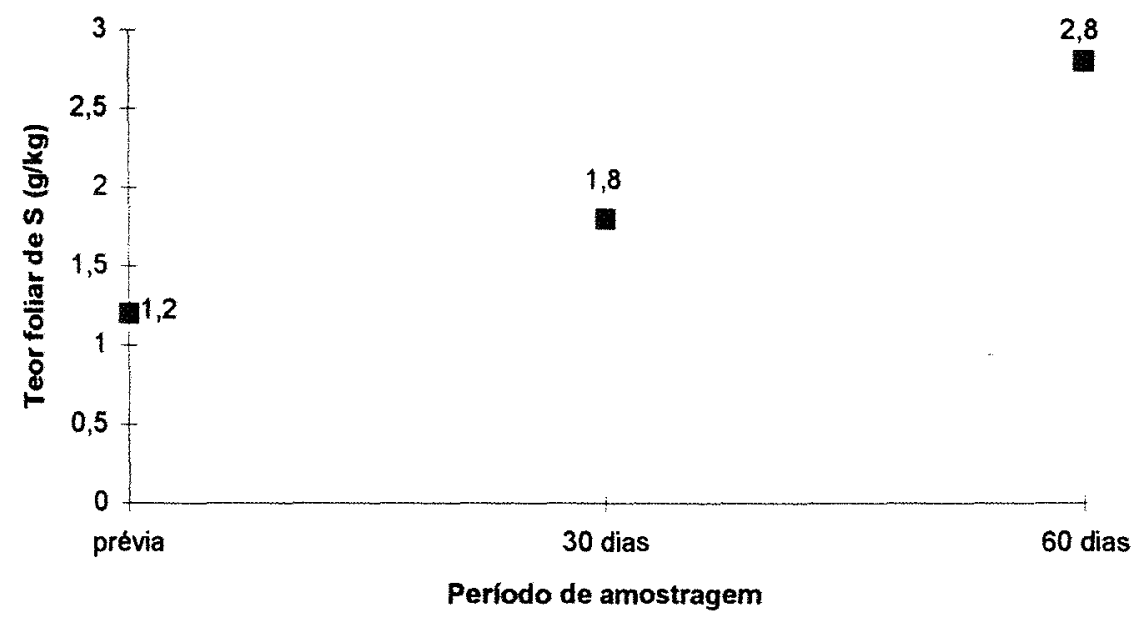

Figura 12. Média dos teores foliares de enxofre encontrados nos períodos de amostragem, (prévia, 30 e 60 dias após a aplicação) na área 2.

Os aumentos foliares de enxofre podem estar relacionados ao fornecimento do elemento via solo pois o fertilizante aplicado foi formulada com o superfosfato simples, 
que contêm enxofre ( $30 \mathrm{~g}$ por planta). Além disso, assim como para o nitrogênio, a mineralização da matéria orgânica, em função do aumento da precipitação neste periodo, deve ter contribuido também para elevação do nível foliar deste nutriente.

\subsubsection{Micronutrientes}

Os resultados da análise foliar para cobre, manganês, zinco e boro nos períodos da florada encontram-se nas Tabelas 18, 19 e 20, respectivamente.

Tabela 18. Teores foliares de $\mathrm{Cu}, \mathrm{Mn}, \mathrm{Zn}$ e $\mathrm{B}$ encontrados imediatamente antes da aplicação na área 2.

\begin{tabular}{|c|c|c|c|c|c|}
\hline $\mathrm{N}^{\mathbf{0}}$ & TRATAMENTOS & $\mathbf{C u}$ & Mn & $\mathbf{Z n}$ & B \\
\hline 1 & Oxicloreto de cobre + M.S. & 6 & 63 & 73 & 36 \\
\hline 2 & Hidróxido de cobre + M.S. & 6 & 68 & 79 & 33 \\
\hline 3 & Oxido cuproso + M.S. & 5 & 68 & 71 & 33 \\
\hline 4 & Benomyl + M.S. & 5 & 70 & 78 & 34 \\
\hline 5 & Oxicloreto de cobre + M.Q. & 5 & 69 & 86 & 34 \\
\hline 6 & Hidróxido de cobre + M.Q. & 6 & 70 & 82 & 32 \\
\hline 7 & Oxido cuproso + M.Q. & 6 & 67 & 74 & 34 \\
\hline 8 & Benomyl + M.Q. & 6 & 72 & 80 & 33 \\
\hline 9 & Testemunha & 6 & 68 & 72 & 33 \\
\hline & Teste F & $0,31^{\text {ns }}$ & $0,72^{\mathrm{ns}}$ & $1,87^{\mathrm{ns}}$ & $0,69^{\mathrm{ns}}$ \\
\hline & DMS & 4,02 & 14,59 & 17,68 & 7,57 \\
\hline & $\mathrm{CV}(\%)$ & 33 & 10 & 11 & 10 \\
\hline
\end{tabular}

Legenda: Doses para 2000 litros de solução.

M.S. = Mistura de Sais: Sulfato de zinco $6,0 \mathrm{~kg}$; Sulfato de manganês $4,0 \mathrm{~kg}$; Ácido bórico $1,0 \mathrm{~kg}$ e Uréia $10,0 \mathrm{~kg}$.

M.Q. $=$ Mistura de Quelados: Ager zinco 0,8 L; Ager manganês 0,8 L; Ager boro 1,0 L e Uréia $10,0 \mathrm{~kg}$. 
Tabela 19. Teores foliares de $\mathrm{Cu}, \mathrm{Mn}, \mathrm{Zn}$ e $\mathrm{B}$ encontrados aos 30 dias após a aplicação na área2.

\begin{tabular}{|c|c|c|c|c|c|}
\hline $\mathrm{N}^{\circ}$ & TRATAMENTOS & $\mathbf{C u}$ & Mn & $\overline{Z n}$ & B \\
\hline I & $\begin{array}{l}\text { Oxicloreto de cobre } \\
\text { M.S. }\end{array}$ & $43 a$ & $56 a b$ & $75 \mathrm{ab}$ & 67 \\
\hline 2 & $\begin{array}{l}\text { Hidróxido de cobre } \\
\text { M.S. }\end{array}$ & $33 \mathrm{ab}$ & $58 \mathrm{ab}$ & $67 \mathrm{abc}$ & 71 \\
\hline 3 & $\begin{array}{l}\text { Oxido cuproso } \\
\text { M.S. }\end{array}$ & $31 \mathrm{ab}$ & $58 \mathrm{ab}$ & $70 \mathrm{abc}$ & 63 \\
\hline 4 & $\begin{array}{l}\text { Benomyl } \\
\text { M.S. }\end{array}$ & $8 b$ & $72 a$ & $87 a$ & 77 \\
\hline 5 & $\begin{array}{l}\text { Oxicloreto de cobre } \\
\text { M.Q. }\end{array}$ & $\overline{43 a}$ & $45 \mathrm{bc}$ & $40 \mathrm{bcd}$ & 70 \\
\hline 6 & $\begin{array}{l}\text { Hidróxido de cobre } \\
\text { M.Q. }\end{array}$ & $43 a$ & $44 \mathrm{bc}$ & $43 b c d$ & 69 \\
\hline 7 & $\begin{array}{l}\text { Oxido cuproso } \\
\text { M.Q. }\end{array}$ & $25 \mathrm{ab}$ & $47 \mathrm{bc}$ & $36 \mathrm{~cd}$ & 71 \\
\hline 8 & $\begin{array}{l}\text { Benomyl } \\
\text { M.Q. }\end{array}$ & $8 \mathrm{~b}$ & $43 \mathrm{bc}$ & $35 \mathrm{~cd}$ & 72 \\
\hline 9 & Testemunha & $9 b$ & $29 c$ & $18 \mathrm{~d}$ & 65 \\
\hline & Teste F & $7,95^{n}$ & $7,45^{\circ *}$ & $9,12^{n}$ & $0,96^{\mathrm{ns}}$ \\
\hline & DMS & 30,75 & 21,23 & 35,66 & 19,48 \\
\hline & $\mathrm{CV}(\%)$ & 36 & 20 & 32 & 13 \\
\hline
\end{tabular}

Legenda: Doses para 2000 litros de solução.

M.S. = Mistura de Sais: Sulfato de zinco 6,0kg; Sulfato de manganês $4,0 \mathrm{~kg}$; Ácido bórico $1,0 \mathrm{~kg}$ e Uréia $10,0 \mathrm{~kg}$.

M.Q.= Mistura de Quelados: Ager zinco 0,8 L; Ager manganês 0,8 Ll; Ager boro 1,0 L e Uréia $10,0 \mathrm{~kg}$. 
Tabela 20. Teores foliares de $\mathrm{Cu}, \mathrm{Mn}, \mathrm{Zn}$ e $\mathrm{B}$ encontrados aos 60 dias após a aplicação na área 2.

\begin{tabular}{|c|c|c|c|c|c|}
\hline $\mathrm{N}^{0}$ & TRATAMENTOS & $\mathrm{Cu}$ & Mn & $\mathrm{Zn}$ & B \\
\hline 1 & $\begin{array}{l}\text { Oxicloreto de cobre } \\
\text { M.S. }\end{array}$ & $33 a$ & $37 \mathrm{a}$ & $27 a$ & 94 \\
\hline 2 & $\begin{array}{l}\text { Hidróxido de cobre } \\
\text { M.S. }\end{array}$ & $15 \mathrm{~cd}$ & $33 a b$ & $22 \mathrm{bcd}$ & 97 \\
\hline 3 & $\begin{array}{l}\text { Oxido cuproso } \\
\text { M.S. }\end{array}$ & $22 b$ & $35 a b$ & $22 \mathrm{bcd}$ & 97 \\
\hline 4 & $\begin{array}{l}\text { Benomyl } \\
\text { M.S. }\end{array}$ & $9 \mathrm{~cd}$ & $32 \mathrm{abc}$ & $28 \mathrm{a}$ & 93 \\
\hline 5 & $\begin{array}{l}\text { Oxicloreto de cobre } \\
\text { M.Q. }\end{array}$ & $34 a$ & $36 a b$ & $25 \mathrm{ab}$ & 93 \\
\hline 6 & $\begin{array}{l}\text { Hidróxido de cobre } \\
\text { M.Q. }\end{array}$ & $13 \mathrm{~cd}$ & $30 \mathrm{abc}$ & $20 \mathrm{~cd}$ & 92 \\
\hline 7 & $\begin{array}{l}\text { Oxido cuproso } \\
\text { M.Q. }\end{array}$ & $16 \mathrm{bc}$ & $34 \mathrm{ab}$ & $18 \mathrm{~d}$ & 92 \\
\hline 8 & $\begin{array}{l}\text { Benomyl } \\
\text { M.Q. }\end{array}$ & $9 \mathrm{~cd}$ & $29 b c$ & $24 a b c$ & 93 \\
\hline$\overline{9}$ & Testemunha & $8 \mathrm{~d}$ & $26 c$ & $18 \mathrm{~d}$ & 94 \\
\hline & Teste F & $45,13^{* *}$ & $5,71^{* *}$ & $12,09^{* *}$ & $0,40^{\mathrm{ns}}$ \\
\hline & DMS & 6,80 & 6,89 & 4,98 & 14.65 \\
\hline & $\mathrm{CV}(\%)$ & 18 & 10 & 10 & 7 \\
\hline
\end{tabular}

Legenda: Doses para 2000 litros de solução.

M.S. = Mistura de Sais: Sulfato de zinco 6,0kg; Sulfato de manganês $4,0 \mathrm{~kg}$; Ácido bórico $1,0 \mathrm{~kg}$ e Uréia $10,0 \mathrm{~kg}$.

M.Q.= Mistura de Quelados: Ager zinco 0,8 L; Ager manganès $0,8 \mathrm{~L}$; Ager boro 1,0 L e Uréia $10,0 \mathrm{~kg}$.

\subsubsection{Cobre}

Os teores foliares de cobre no dia da aplicação encontravam-se na faixa de $6 \mathrm{~g} / \mathrm{kg}$, considerados dentro da faixa adequada para esta variedade de laranja, segundo GPACC (1994) (Tabela 18).

Após 30 dias da aplicação, encontrou-se um aumento significativo nos teores foliares de cobre em todos os tratamentos em que foi incluido algum fungicida cúprico.

As plantas tratadas com oxicloreto de cobre (Tratamentos 1 e 5) e com hidróxido de cobre associado com a mistura de quelados (Tratamento 6), apresentam uma 
tendência de manter um teor foliar de cobre mais elevado que os demais tratamentos, aos 30 dias (Tabela 19). Nas plantas tratadas com oxicloreto de cobre (Tratamentos 1 e 5) esse fato pode ser explicado pela presença do ânion cloreto na solução, o que já foi observado por Vitti et al., (1996).

As plantas que receberam óxido cuproso (Tratamentos 3 e 7) apresentaram teores foliares inferiores aquelas dos demais tratamentos que receberam alguma fonte de cobre após 30 dias. Evidentemente os menores teores foliares de cobre após 30 dias foram encontrados nas plantas que não receberam nenhum fungicida (Tratamento 4 e 8) que foram iguais a testemunha (Tratamento 9).

A amostragem realizada aos 60 dias parecem confirmar as tendências encontradas aos 30 dias. Os maiores teores foliares em ordem decrescente foram verificados nas plantas que receberam fungicida oxicloreto de cobre (Tratamentos 1 e 5), em seguida as plantas tratadas com óxido cuproso (Tratamentos 3 e 7) e hidróxido de cobre (Tratamentos 2 e 6). As plantas tratadas com benomyl (Tratamentos 4 e 8) e a testemunha (Tratamento 9) continuaram com os menores teores foliares de cobre, praticamente iguais a situação inicial (época da florada). Os teores foliares de cobre, estão apresentados na Figura 13.

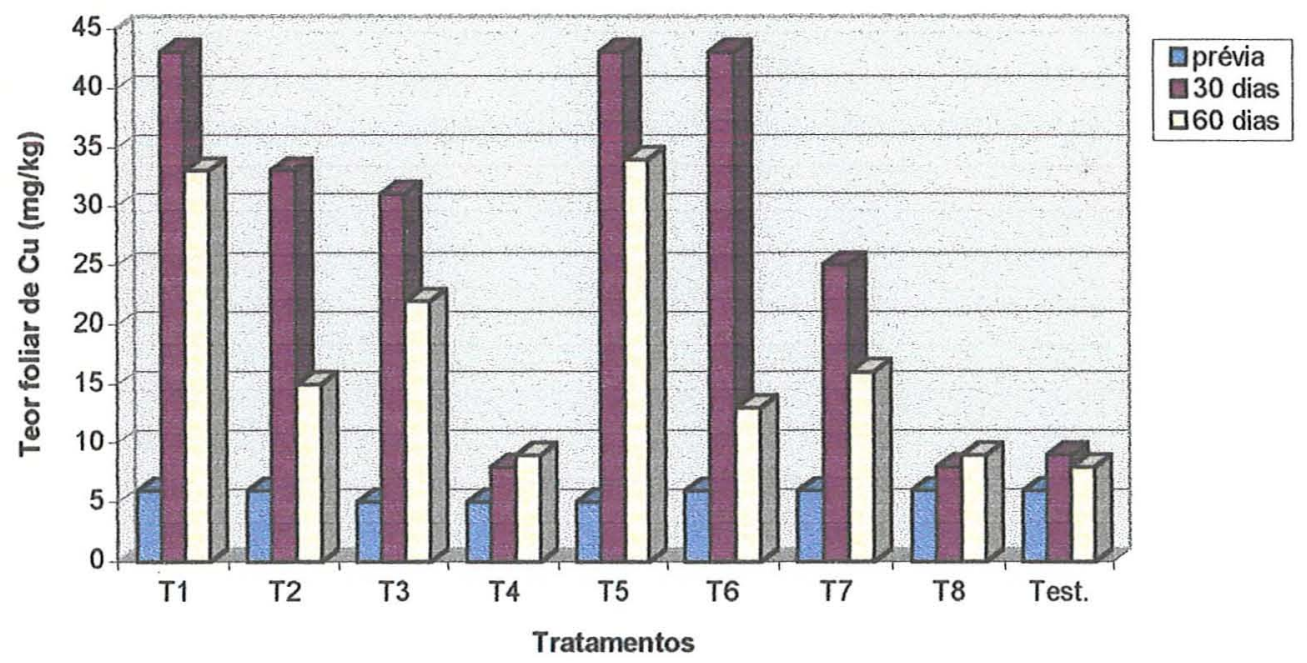

Figura 13. Teores foliares de cobre encontrados em três épocas de amostragem (prévia, 30 e 60 dias após a aplicação) nos tratamentos da área 2. 
Observou-se nos resultados encontrados na figura 13, que não houve diferença entre os tratamentos que receberam mistura de sais em relação àqueles que receberam mistura de quelados, para o teor foliar de cobre, e que as diferenças estão praticamente relacionadas apenas com o fungicida cúprico utilizado. Embora menores, os teores foliares aos 30 e 60 dias apresentados pelos tratamentos que não receberam nenhuma fonte de fungicida cúprico, são considerados adequados para a variedade de citros utilizada no experimento segundo GPACC (1994). Além disso, os teores foliares foram mantidos pelas plantas durante os 3 periodos em que houve amostragem. Isto pode ser explicado por um eventual acúmulo deste elemento em função de sucessivas aplicações com fungicidas cúpricos, ocorridas em anos anteriores nesta área, além de uma provável presença do elemento no solo (principalmente na matéria orgânica) em teores suficientes para atender parte da demanda da planta.

Conforme observaram, Malavolta et al. (1989) e Vitti (1992), a ocorrència de deficiência de cobre no estado de São Paulo, geralmente está relacionada a condição de solos pobres no elemento e as variedades exigentes, como é o caso da variedade Westin, situações estas que diferem daquelas em que foram conduzidos os experimentos.

\subsubsection{Manganês}

Em relação ao manganês foram encontrados teores foliares considerados altos pelo GPACC (1994) na amostragem realizada no dia da primeira pulverização (época da florada) conforme pode ser observado na tabela 18 .

A amostragem realizada aos 30 dias já indicam diferenças significativas entre os diversos tratamentos (Tabela 19). O maior teor foliar de manganês foi observado nas plantas que receberam a mistura de sais acrescida de benomyl (Tratamento 4). Os demais tratamentos com mistura de sais associada aos fungicidas cúpricos (Tratamentos 1 , 2 e 3) apresentaram teores foliares iguais entre si e inferiores ao tratamento 4.

Esta diferença pode ser explicada pela ocorrência de possivel antagonismo ocorrido entre o cobre e o manganês uma vez que o tratamento 4, que não recebeu cobre, acarretou o maior teor foliar de manganês. Embora houvessem estas diferenças, os teores foliares deste micronutriente nestes tratamentos são considerados altos. 
As plantas que receberam mistura de quelados (Tratamentos 5, 6,7 e 8) apresentaram-se com os mesmos teores foliares de manganês entre si, os quais foram inferiores àquelas que receberam misturas de sais.

Neste caso não encontrou-se valores diferentes no tratamento sem fungicida cúprico (Tratamento 8). Este resultado provavelmente deve-se ao fato do manganès contido na mistura de quelados encontrar-se complexado, reduzindo com isso o seu comportamento iônico e ficando como que protegido das possiveis reações antagônicas com o íon cobre contido naqueles fungicidas (Tratamentos5, 6 e 7) conforme foi observado por Malavolta (1994) e Tisdale et al. (1985).

Embora aos 30 dias os teores de manganês nas plantas que receberam mistura de quelados (Tratamentos 5,6 e 7) sejam inferiores àquelas que foram tratadas com mistura de sais, estes teores estavam dentro da faixa dos adequados. Considerando que a quantidade do elemento $\mathrm{Mn}$ fornecida pelos quelados é praticamente dez vezes menor que os sais (Tabela 7) observou-se uma eficiência bastante superior desta fonte pelo parâmetro teor foliar aos 30 dias após a aplicação.

O menor teor foliar de manganês foi encontrado, como era de se esperar, na testemunha (Tratamento 9) que foi praticamente a metade da inicial, época da florada, atingindo teores considerados baixos. Considerando amostragem em folhas maduras e a baixa mobilidade na planta do manganês infere-se que houve uma grande demanda por este micronutriente neste periodo.

A Figura 14, apresenta as variações nos teores foliares de manganès nas 3 épocas amostradas. 


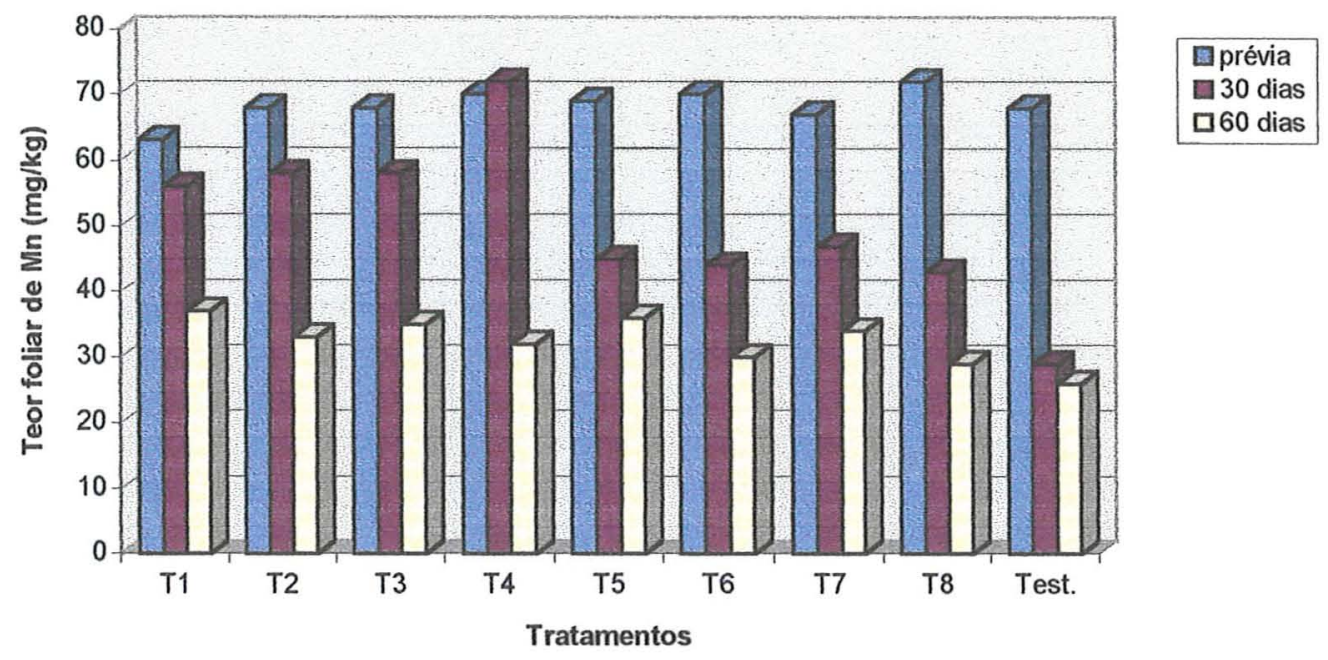

Figura 14. Teores foliares de manganês encontrados em três épocas de amostragem (prévia, 30 e 60 dias após a aplicação) nos tratamentos da área 2.

Após 60 dias da aplicação na florada encontrou-se uma redução geral nos teores foliares de manganês (Tabela 20), ficando no limite de valores considerados baixos, indicando a necessidade de um novo fornecimento confirmando as recomendações oficiais (GPACC, 1994).

As árvores que receberam oxicloreto de cobre (Tratamentos 1 e 5 ) apresentaram valores ligeiramente superiores nos teores foliares de manganês.

Neste período de amostragem praticamente não encontrou-se diferenças entre os teores foliares das plantas que receberam mistura de sais (Tratamentos 1, 2, 3 e 4) daquelas que receberam mistura de quelados (Tratamentos 5, 6, 7 e 8).

A testemunha apresentou o menor teor foliar de manganês aos 60 dias após a aplicação.

\subsubsection{Zinco}

Os teores foliares de zinco na área 2 encontram-se uniformes entre as plantas, com valores consideradas altos conforme apresentado na tabela 18. A amostragem 
realizada aos 30 dias (Tabela 19) apresentou o tratamento com mistura de sais e benomyl (Tratamento 4) como o de maior teor foliar de zinco, o que pode indicar um possivel efeito da ausência de competição entre o cobre e o zinco.

Os tratamentos com mistura de sais associados aos fungicidas cúpricos (Tratamentos 1, 2 e 3) apresentaram teores pouco inferiores ao tratamento 4 aos 30 dias, não havendo diferenças entre estes três tratamentos.

Este fato deve estar associado ao efeito de inibição competitiva conforme observado por Swietlik \& LA Duke (1991) e Vitti (1992) embora tenha sido acrescentado uréia à mistura .

Os teores foliares de zinco aos 30 dias, das plantas tratadas com mistura de quelados (Tratamentos 5, 6,7 e 8), apresentaram-se menores que os das plantas que receberam a mistura de sais, embora permanecessem em patamares considerados adequados para o teor foliar de zinco (Tabela 11).

$O$ fato de não haver diferenças significativas entre os teore foliares das plantas que receberam mistura de quelados com fungicidas cúpricos (Tratamentos 5,6 e 7) e o tratamento com benomyl mais mistura de quelados (Tratamento 7) pode ser explicado pelo complexo formado entre o íon zinco e a molécula orgânica quelatizante, impedindo as interações entre o zinco e o cobre levando a uma ausência de diferenças entre estes quatro tratamentos aos 30 dias conforme observou Malavolta (1994) e Tisdale et al. (1985). Além disso, notou-se também uma eficiência relativa maior dos quelados sobre a mistura de sais, uma vez que a primeira forneceu uma quantidade aproximadamente oito vezes menor do elemento em relação a segunda (Tabela 7) e permitiu a manutenção de teores foliares adequados confirmando Wallace (1966) e Anderson (1968).

A demanda por zinco pela planta neste periodo de 60 dias foi bastante elevada pois assim como para o manganês os teores foliares de zinco nas plantas que não receberam suplementação cairam acentuadamente (Figura 15) conforme já tinha sido observado na área 1. 


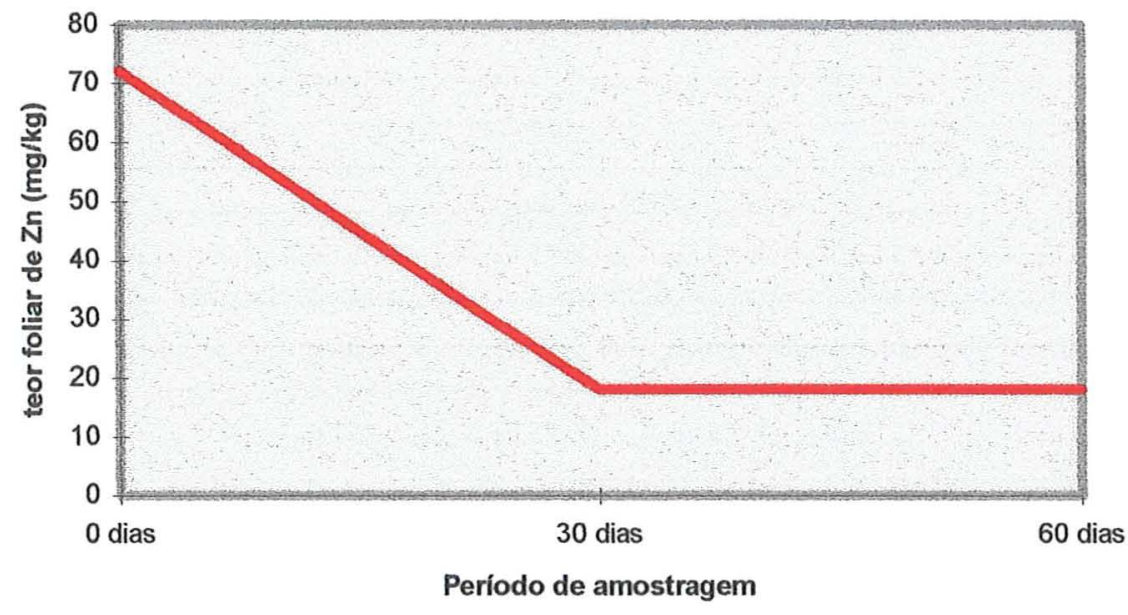

Figura 15. Teores foliares de zinco encontrados nos período de amostragem (prévia, $30 \mathrm{e}$ 60 dias após a aplicação) na testemunha da área 2.

A Figura 16, apresenta os resultados de análise de folha para zinco na área 2, nas três épocas de amostragem.

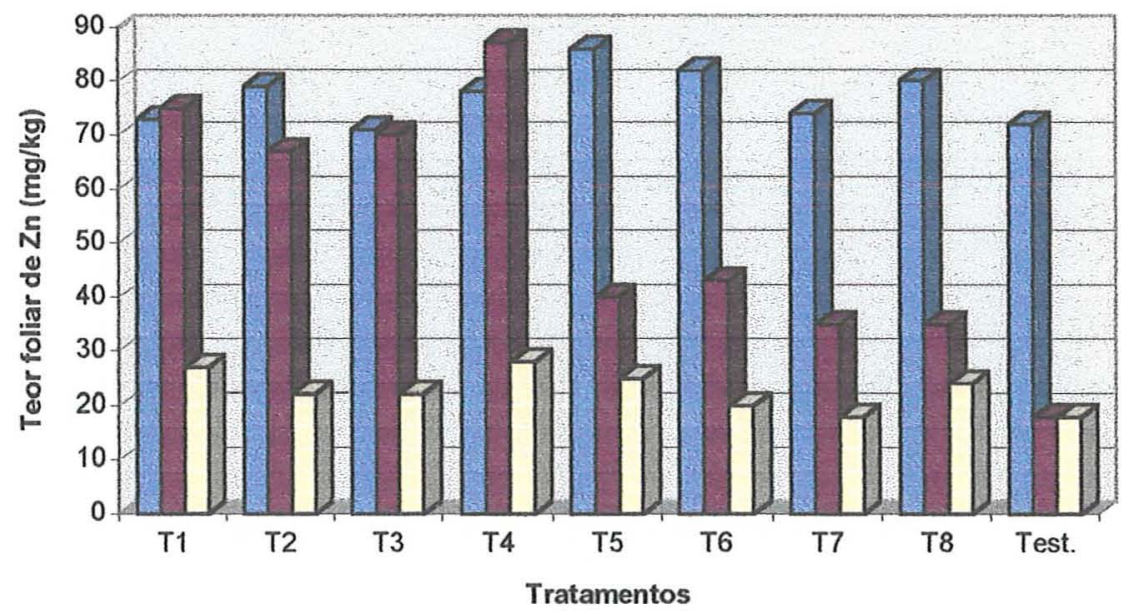

Figura 16. Teores foliares de zinco encontrados em três épocas de amostragem (prévia, $30 \mathrm{e}$ 60 dias após a aplicação) nos tratamentos da área 2. 
Após 60 dias os teores foliares das plantas de todos os tratamentos caíram em relação ao levantamento anterior (Tabela 20), ficando todos na faixa de deficiência (Tabela 11).

Os maiores teores foram encontrados nos tratamentos com benomyl e oxicloreto de cobre tanto em associação com a mistura de sais quanto com a mistura de quelados (Tratamentos 1, 4, 5 e 8).

Os tratamentos que receberam hidróxido de cobre e óxido cuproso, quer com mistura de sais como com mistura de quelados, apresentaram os menores teores foliares de zinco após 60 dias de sua aplicação.

\subsubsection{Boro}

Em relação ao teor foliar de boro não foram encontradas diferenças significativas entre os tratamentos (Tabelas 18, 19 e 20).

Houve um aumento nos teores foliares entre a época da florada (primeira amostragem) até 60 dias após em todas as plantas amostradas (Figura 17).

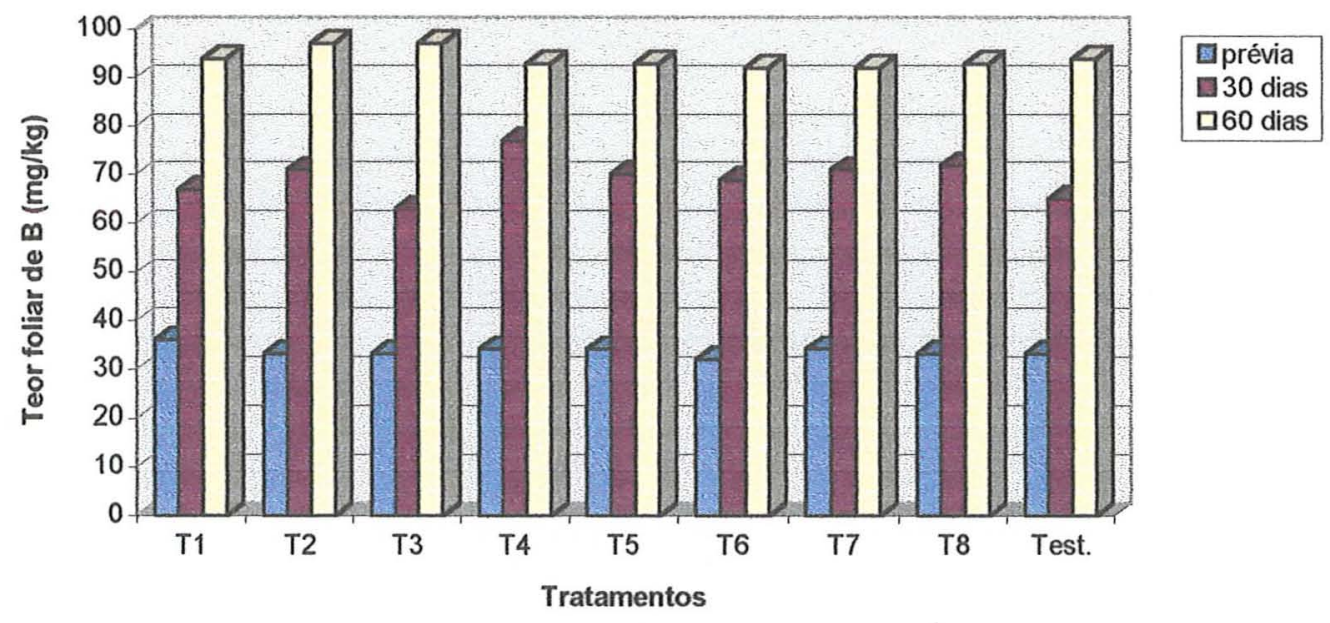

Figura 17. Teores foliares de boro encontrados em três épocas de amostragem (prévia, $30 \mathrm{e}$ 60 dias após a aplicação) nos tratamentos da área 2.

O fornecimento de boro via solo feito na área anteriormente a instalação do experimento, aliado a precipitação ocorrida no período (Tabela 1), que contribuiu para a 
mineralização da matéria orgânica, favoreceram a manutenção de teores adequados na planta durante o periodo avaliado.

Assim, como ocorreu na área 1 , não houve diferenças no teor foliar de boro entre as plantas que receberam este elemento e a testemunha provavelmente devido ao melhor aproveitamento do boro presente no solo em comparação com o aplicado via foliar.

A primeira amostragem realizada na área 2 apresentou teores foliares de boro menores em relação a área 1 (um ano antes). Este fato pode ser explicado pela ocorrência da forte seca ocorrida nos meses anteriores à instalação do experimento (inverno de 1994) na área 2 (Tabela 1). 


\section{CONCLUSÕES}

Nas condições em que foram conduzidos os experimentos pode-se concluir que:

- Os teores foliares de manganès e zinco tenderam a cair sensivelmente durante os 60 dias após a florada, atingindo teores deficientes, indicando que a manutenção dos teores foliares dos mesmos exige nova aplicação foliar após 60 dias da florada;

- A aplicação dos fungicidas cúpricos como oxicloreto, hidróxido e óxido cuproso nas dosagens recomendadas resultou no aumento do teor foliar de cobre, mantendo-se excessivos após 30 e 60 dias sendo que o fungicida cúprico que resultou em maior teor foliar de cobre aos 30 e 60 dias após a aplicação foi o oxicloreto, seguido do óxido cuproso e do hidróxido de cobre;

- O fungicida mancozeb foi capaz de elevar e manter adequado o teor de manganês foliar, mesmo fornecendo a metade da dose do elemento em relação ao sulfato de manganês após 60 dias da sua aplicação;

- A aplicação de fungicidas cúpricos, principalmente o óxido cuproso, associada com sulfato de manganês e de zinco reduziu o teor foliar de manganês e zinco, o mesmo não foi observado quando estes micronutrientes foram fornecidos na forma de quelados;

- O fornecimento de manganês e zinco na forma de quelados apresentou eficiência relativa maior do que os sais de sulfato, em relação a quantidade aplicada, na ordem de 10:1 e 8:1, respectivamente;

- A aplicação de boro via foliar não alterou os teores foliares desse elemento 30 e 60 dias após esta prática. 


\section{REFERÊNCIAS BIBLIOGRÁFICAS}

ALVA, A.K.; GRAHAM, J.H.; TUCKER, D.P.H. Role of calcium in amelioration of copper phytotoxicity for citrus. Soil Science, v. 155, n.3, p.211-218, 1993.

ALVAREZ, C. Utilização de quelatos em adubação foliar. In: SIMPÓSIO BRASILEIRO DE ADUBAÇÃO FOLIAR, 2., Botucatu, 1987. Adubação foliar: Anais. Campinas: CARGILL; 1991. p. 177-189.

BACHA, M.A.A. Responses of "Succary" and "balady" orange tree to foliar sprays of zinc and copper. Indian Journal of Agricultural Sciences, v. 45, n.5 p.189-193, 1975.

BATAGLIA, O.G.; RODRIGUEZ, O.; HIROCE, R.; GALLO, J.R.; FURLAN, P.R.; FURLANI, A.M.C. Composição mineral de frutos cítricos na colheita. Bragantia, v.36, n.21, p.215-221, 1977.

BORKERT, C.M. Manganês. In: SIMPÓSIO SOBRE MICRONUTRIENTE NA AGRICULTURA, 1., Jaboticabal, 1988. Micronutrientes na agricultura : anais Piracicaba: POTAFOS; CNPq, 1991. p.173-189.

CABRITA, J.R.M. Aplicação de boro, manganês e zinco em citros, via solo e foliar. Jaboticabal, 1993. 47p. Dissertação - Faculdade de Ciências Agrárias e Veterinárias, Universidade Estadual Paulista Júlio de Mesquita Filho.

DECHEN, A.R.; HAAG. H.P.; CARMELLO, Q.A. Micronutrientes: diagnose visual. In: SIMPÓSIO SOBRE MICRONUTRIENTES NA AGRICULTURA, 1 Jaboticabal, 1988. Micronutrientes na agricultura: anais. Piracicaba: POTAFOS; CNPq, 1991 a. p.273-288. 
DECHEN, A.R.; HAAG, H.P.; CARMELLO, Q.A.C. Funções dos micronutrientes nas plantas. In: SIMPÓSIO SOBRE MICRONUTRIENTES NA AGRICULTURA, 1., Jaboticabal, 1988. Micronutrientes na agricultura: anais. Piracicaba: POTAFOS; CNPq, 1991b. p.65-97.

DESZYCK, E.J. Boron deficiency. In: PRATT, R.M., (Ed.) Florida guide to citrus insects, diseases and nutritional disorders in color. Gainesviele: Agricultural Experiment Station, 1958. p. 64 .

Du PLESSIS, C.J. Relação entre elementos nutricionais, produção e qualidade dos citros. In: SEMINÁRIO INTERNACIONAL DE CITROS, 2., Bebedouro, 1992. Campinas: Fundação Cargill, 1992. p.121-131.

FALLAHI, E. Tree canopy volume and leaf mineral concentrations of "Red blush" grapefuit on twelve rootstocks. Fruit Varieties Journal, v. 46, n. 1, p.44-48, 1992.

FALLAHI, E.; MASON, R.E.; RODNEY, D.R. Influence of rootstocks on orlando tangelo leaf elemental concentration. Comunications in Soil Science and Plant Analysis, v. 22, p.11-12, 1991.

FERREIRA, N.E.; CRUZ, M.C.P. da. Cobre. In: SIMPÓSIO SOBRE MICRONUTRIENTES NA AGRICULTURA, 1., Jaboticabal, 1988. Micronutrientes na agricultura: anais. Piracicaba: POTAFOS; CNPq, 1991. p.131-171.

GRUPO PAULISTA DE ADUBAÇÃO E CALAGEM PARA CITROS. Recomendações de adubação e calagem para citros no Estado de São Paulo. 3. (Ed.) Cordeirópolis, 1994. $27 \mathrm{p}$.

HIROCE, R.; CAETANO, A.R. Levantamento nutricional de pomares cítricos pela análise química foliar. Laranja, v.5, p.265-276, 1984.

KAMPFER, M.; UEXKULL, H.R. von. Nuevos conocimientos sobre la fertilizacion de los cítricos. 3. (Ed.) Hannover: Verlags Gesellschatf fur Ackerbau, 1963. 104p. 
KOO, R.C.J. Nutrição e adubação dos citros. In: YAMADA, T., (Ed.) Nutrição mineral e adubação do citros. Piracicaba: Instituto Internacional da Potassa e Fosfato, 1979. p.99-122. (Boletim Técnico, 5).

LEONARD, C.D.; STEWART, I. Zinc deficiency. In: PRATT, R.M., (Ed.). Florida guide to citrus insects diseases and nutritional disorders in color. Gainesville: Agricultural Experiment Station, 1958. p.46.

LINDSAY, W.L. Zinc in soils and plant nutrition. Advances in Agronomy, v. 24, p.147186,1972 .

MALAVOLTA, E. Manual de química agrícola. São Paulo: Agronômica Ceres, 1976. $528 \mathrm{p}$.

MALAVOLTA, E. Nutrição mineral e adubação dos citros. In: YAMADA, T. (Ed.) Nutrição mineral e adubação dos citros. Piracicaba: Instituto Potassa e Fosfato, Inst. Internacional de Potassa, 1979. p.13-72. (Boletim Técnico, 5).

MALAVOLTA, E. Quelado em citricultura - o que são e para que servem. Informativo Coopercitrus, v. 8, n. 93, p. 18-20. 1994.

MALAVOLTA, E.; VIOLANTE NETTO, A. Nutrição mineral, calagem, gessagem e adubação dos citros. Piracicaba: POTAFOS, 1989. 153p.

MALAVOLTA, E.; VITTI, G.C.; OLIVEIRA, S.A. de. Avaliação do estado nutricional das plantas: princípios e aplicações. Piracicaba: Associação Brasileira para pesquisa de Potassa e do Fosfato, 1989. 201 p.

MANN, M.S.; TAKKAR, P.N. Antagonism of micronutrient cations on sweet oranges leaves. Scientia Horticulturae, v.20, n.3, p.259-265, 1983. 
OLSEN, S. R. Micronutrients interactions In: MORTVEDT, J.J.; GIORDANO, P.M.; LINDSAY, W.L. (Ed.) Micronutrients in agriculture. Madison; SSSA, 1972. p. 243261.

REITZ, H.J. Cooper deficiency. In: PRATT, R.M. (Ed.) Florida guide to citrus insects, diseases and nutritional disorders in color. Gainesville: Agricultural Experiment Station, 1958a. p.52.

REITZ, H.J. Manganese deficiency. In: PRATT, R.M. (Ed.) Florida guide to citrus insects, diseases and nutritional disorders in color. Gainesville: Agricultural Experiment Station, 1958b. p.48.

RODRIGUEZ, O. Adubação dos citros, situação dos pomares paulistas. In: YAMADA, T. (Ed.) Nutrição mineral e adubação dos citros. Piracicaba: Inst. Potassa e Fosfato, 1979. p.73-98. (Boletim Técnico, 5).

RODRIGUEZ, O. Aspectos fisiológicos, nutrição e adubação dos citros. In: RODRIGUEZ, O.; VIEGAS, F. (Ed.) Citricultura brasileira. 2 (Ed.) Campinas. Fundação Cargill, 1991. v. 1, p.419-475.

SOUZA, E.C.A. de.; FERREIRA, M.E. Zinco. In: SIMPÓSIO SOBRE MICRONUTRIENTES NA AGRICULTURA, 1., Jaboticabal, 1988. Micronutrientes na agricultura: anais. Piracicaba: POTAFOS; CNPq. 1991. p.219-236.

STEYN, W.J.; EVE, D.J. The zinc status and pineapple in the Eastern Cape. South African Journal Science, p.52-270, 1956.

SWIETLIK, D.; La DUKE, J.V. Productivity, growth and leaf mineral composition of orange and grapefruit trees foliar sprayed with zinc and manganese. Journal of Plant Nutrition, v.14, n.2, p.129-142, 1991.

TISDALE, S. L.; NELSON, W. L.; BEATON, J. D. Soil fertility and fertilizers. New York: Macmillan, 1985. 754p. 
VITTI, G.C. Amostragem e interpretação da análise de solo e de folha na citricultura. Jaboticabal: FUNEP, 1988. 32p.

VITTI, G. C. Ação dos micronutrientes na produção de laranja Pêra. Informativo Coopercitrus, v. 5, n. 54, p.20-24. 1991.

VITTI, G.C. Nutrição e crescimento de plantas cítricas. In: DONADIO, L.C. coord. SEMINÁRIO INTERNACIONAL DE CITROS, 2., Bebedouro, 1992. Campinas: Fundação Cargill, 1992. p.132-162.

VITTI, G. C.; DOSUALDO, L. B.; ALMEIDA, M. C. de ; NAKAYAMA, L. H. I.; SILVA, M. M. Comparação de fontes de cobre no controle de "galhos secos" e na nutrição de citros. In: CONGRESSO LATINO AMERICANO DE CIENCIA DO SOLO, 13., Águas de Lindóia. 1996. 